ERnest ORLANDO LAWRENCE BERKELEY NATIONAL LABORATORY

Environmental Energy Technologies Division

Reassessing Wind Prtential Estimates for India: Econom/c and Policy Implications

Amol Phadke

Ranjit Bharvirkar

Jagmeet Khangura
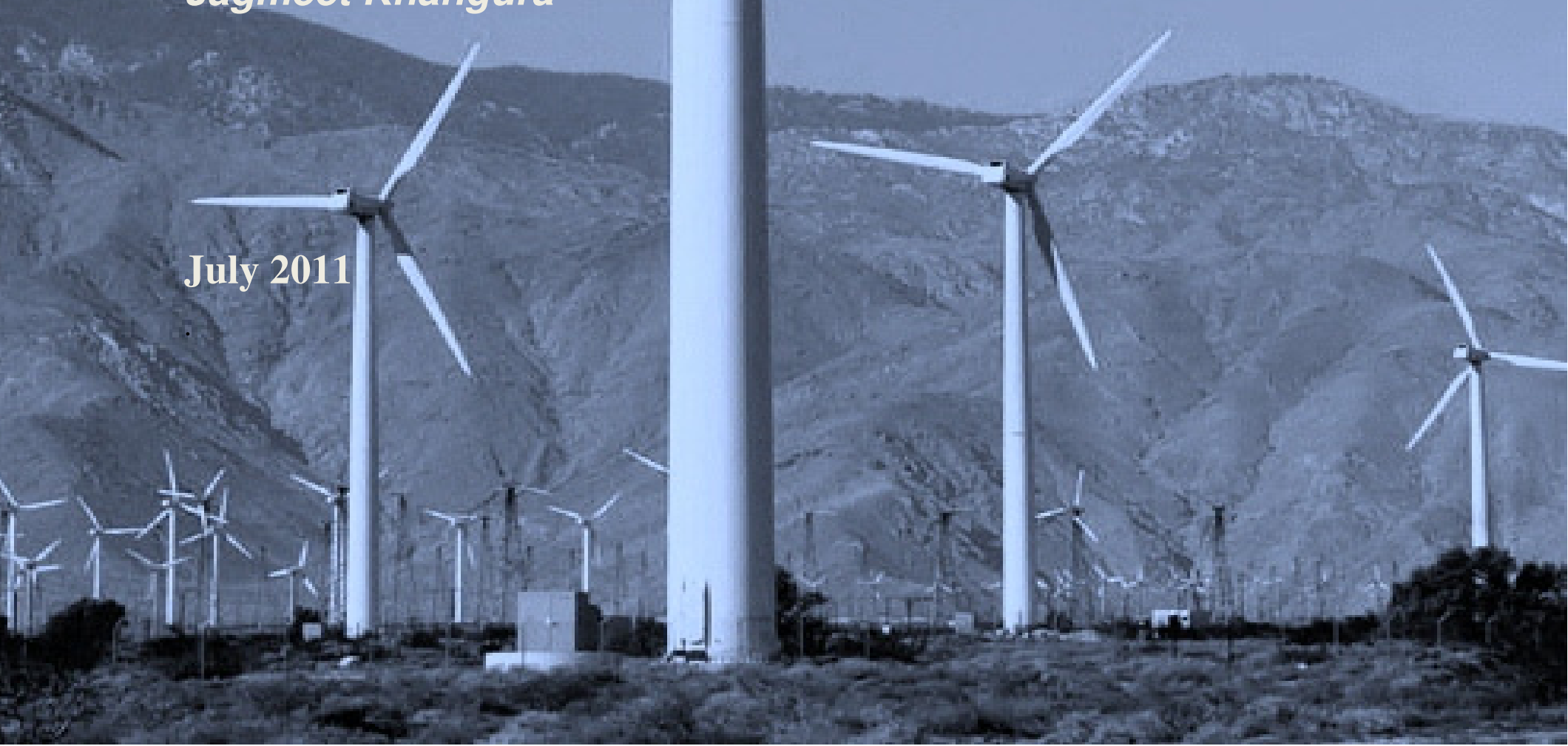


\section{Reassessing Wind Potential Estimates for India: Economic and Policy Implications}

Amol Phadke, Ranjit Bharvirkar, and Jagmeet Khangura

\section{Table of Contents}

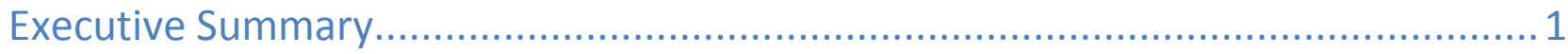

1 Background and Motivation ........................................................... 7

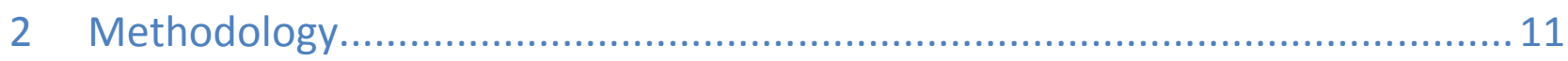

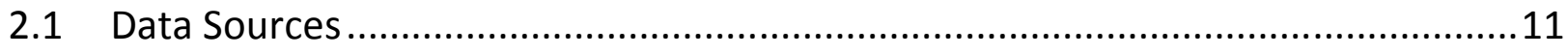

2.1.1 Wind Power Density and Wind Speed Data ............................................... 11

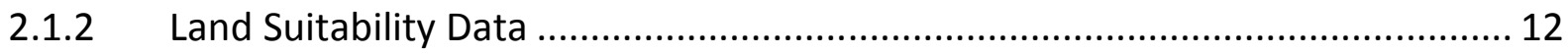

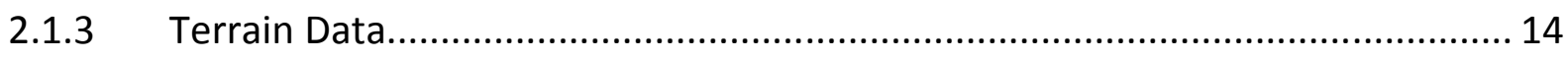

2.1.4 Protected Areas Data .......................................................................... 15

2.2 Estimation of Technical Potential from Wind Power Density and Wind Speed .....15

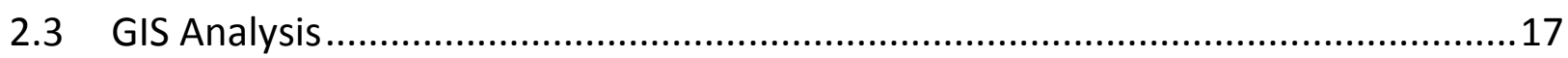

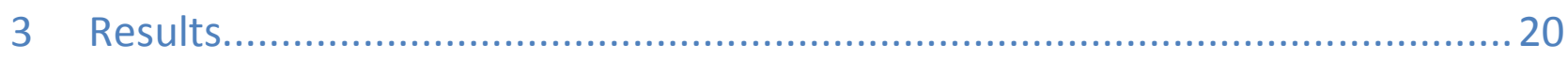

3.1 Coincidence of Wind Generation with Seasonal Load Shapes at National and

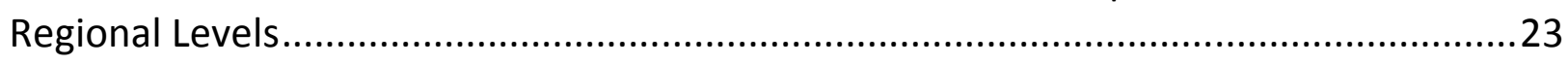

3.2 Coincidence of Wind Generation with Diurnal Load Shapes at a National level and Regional Levels...................................................................................... 25

4 Conclusions and Future Directions .................................................. 27

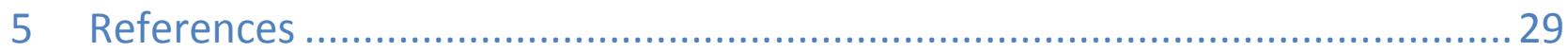




\section{Abstract}

We assess developable on-shore wind potential in India at three different hub-heights and under two sensitivity scenarios - one with no farmland included, the other with all farmland included. Under the "no farmland included" case, the total wind potential in India ranges from 748 GW at $80 \mathrm{~m}$ hub-height to $976 \mathrm{GW}$ at $120 \mathrm{~m}$ hub-height. Under the "all farmland included" case, the potential with a minimum capacity factor of 20 percent ranges from $984 \mathrm{GW}$ to 1,549 GW. High quality wind energy sites, at $80 \mathrm{~m}$ hub-height with a minimum capacity factor of 25 percent, have a potential between $253 \mathrm{GW}$ (no farmland included) and $306 \mathrm{GW}$ (all farmland included). Our estimates are more than 15 times the current official estimate of wind energy potential in India (estimated at $50 \mathrm{~m}$ hub height) and are about one tenth of the official estimate of the wind energy potential in the US.

\section{Executive Summary}

\section{Motivation}

Wind potential estimates in India need to be reassessed for three reasons. First, two recent studies - one conducted by experts from Harvard University and the Technical Research Center of Finland (published in the Proceedings of the National Academy of Sciences) and the other by experts from The Energy Resources Institute (India) - estimate on-shore wind potential in India to be $>1,000 \mathrm{GW}$ (estimated at hub heights $>=80 \mathrm{~m}$ ). ${ }^{1}$ In sharp contrast, the official wind energy potential estimate (by the Center for Wind Energy Technologies (CWET), India) used by the Indian government in its policy-making process is only $49 \mathrm{GW}$ (estimated at a hub height of $50 \mathrm{~m}) .{ }^{2}$ Second, recent reassessments conducted in various countries such as the U.S. and China have found much higher wind energy potential due to better technology in the form of higher efficiency, hub heights, and sizes of wind turbines. The official wind potential estimates (expressed in capacity terms) used by China have recently increased by $800 \%$ and those of the U.S. by $50 \%$ (see Figure ES 1). Wind potential estimates for US expressed in terms of energy have increased almost 400\%. Third, systematic analysis based on Geographic Information System (GIS) data provides an accurate way to identify land with wind power development potential. The potential estimate by CWET presented in the 2010 Indian Wind Atlas assumes that just two percent of the windy land is available for wind energy development without explicitly stating the underlying rationale. All three reasons taken together suggest that reassessment of the wind resource in India could also reveal a substantially higher potential than previously estimated and could potentially have major implications of Indian power sector policy.

\section{Methodology}

In this study, wind energy potential for turbines at $80 \mathrm{~m}, 100 \mathrm{~m}$, and $120 \mathrm{~m}$ hub-heights was estimated at varying levels of capacity utilization factors. The hub-height of the most commonly sold wind turbines today is $80 \mathrm{~m}$. In general, the trend is toward steadily growing hub-heights,

\footnotetext{
${ }^{1}$ Hossain J, et al., 2011. A GIS based Assessment of Potential for Wind Farms in India, Renewable Energy (2011), doi:10.1016/j.renene.2011.04.017 and Xi Lu et al. (2010). Global Potential for Wind Generated Electricity. Proceedings of the National Academy of Sciences, April.

${ }^{2}$ Center for Wind Energy Technology and Riso DTU National Laboratory for Technology, 2010. Indian Wind Atlas, Chennai, India.
} 
with most major wind turbine manufacturers now offering turbines with hub-heights $>100 \mathrm{~m}$ and some as high as $150 \mathrm{~m}$.

Annual average wind power density and wind speed data at an elevation of $80 \mathrm{~m}, 100 \mathrm{~m}$, and $120 \mathrm{~m}$ for each 5 -square-km cell in India was procured from 3 Tier. ${ }^{3}$ Publicly available GIS data on topography and land use was used to exclude areas where development of wind facilities would be problematic. The excluded sites included low quality wind areas (wind power density < $200 \mathrm{~W} / \mathrm{m}^{2}$ ), areas with slopes greater than 20 degrees, elevation greater than $1500 \mathrm{~m}$, forests, snow-covered areas, water bodies, urban areas, and protected areas from the World Database of Protected areas.

POTENTIAL (MW)

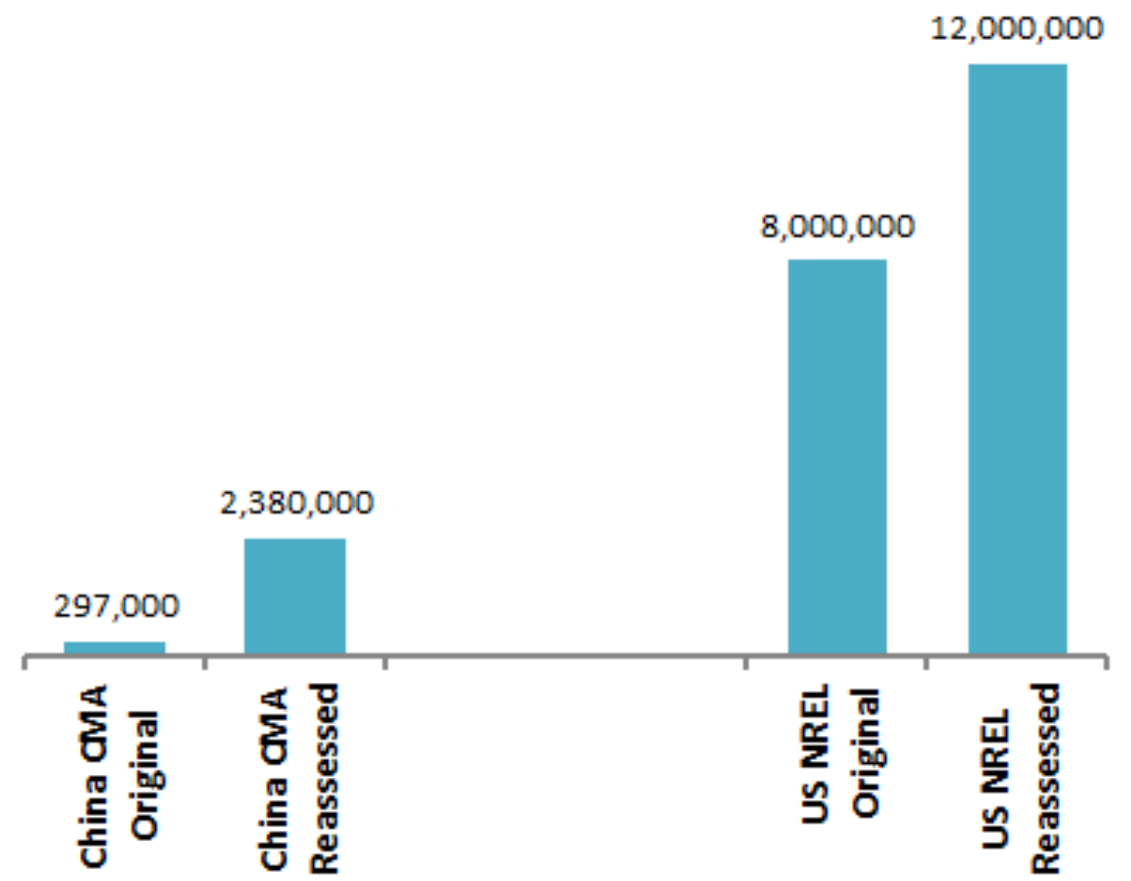

Figure ES 1. Results of Wind Potential Reassessments in US and China

Source:

US Original: Described in Black \& Veatch, "20 Percent Wind Energy Penetration in the United States: A Technical Analysis of the Energy Resource." Retrieved 7 August, 2011 from:

http://www.20percentwind.org/Black_Veatch_20_Percent_Report.pdf. US reassessed -described in Elliott et al., 2010. New Wind Maps and Resource Potential Estimates for the United States. Retrieved from: http://www.nrel.gov/docs/fy11osti/50439.pdf.

China original and reassessed based on studies by China Meteorological Association (CMA) described in Li Junfeng et al., 2010 China Wind Power Outlook, October 2010, downloaded on 27/06/2011 from http://www.gwec.net/fileadmin/documents/test2/wind\%20report0919.pdf

As observed in locations around the world, land can be used simultaneously for wind energy production and for agriculture (for example, farming, cattle-raising, etc.). Hence, a sensitivity

\footnotetext{
${ }^{3}$ http://www.3tier.com/en/package_detail/wind-speed-gis-data-layer/
} 
analysis was conducted with respect to the amount of farmland that is available for wind energy development after applying the previously stated exclusions.

\section{$\underline{\text { Key Findings }}$}

Figure ES 2 shows developable on-shore wind potential at three different hub-heights and under two sensitivity scenarios - one with no farmland included, the other with all farmland included. Under the "no farmland included" case, the total wind potential in India ranges from $748 \mathrm{GW}$ at 80m hub-height to $976 \mathrm{GW}$ at $120 \mathrm{~m}$ hub-height.

Under the "all farmland included" case the potential with a minimum capacity factor of 20 percent ranges from $984 \mathrm{GW}$ to 1,549 GW. As seen in Figure ES 2, most of the wind energy potential is in the lower capacity wind energy sites. High quality wind energy sites alone have a potential at $80 \mathrm{~m}$ hub-height with a minimum capacity factor of 25 percent between $253 \mathrm{GW}$ (no farmland included) and $306 \mathrm{GW}$ (all farmland included) - more than five times the current official estimate.

As seen from the map in Figure ES 3, more than 95 percent of the wind energy potential is concentrated in just five states in southern and western India - Tamil Nadu, Andhra Pradesh, Karnataka, Maharashtra, and Gujarat. The state with the overall largest resource is Karnataka while the state with largest best-quality resource is Tamil Nadu. From a cost-effective perspective, the full development of best-quality wind resources in Tamil Nadu - which already leads all states in installed wind capacity - would yield a capacity of $31 \mathrm{GW}$ at a $120 \mathrm{~m}$ hubheight and a minimum capacity factor of $36 \%$. This is more than twice the total installed wind capacity in India.

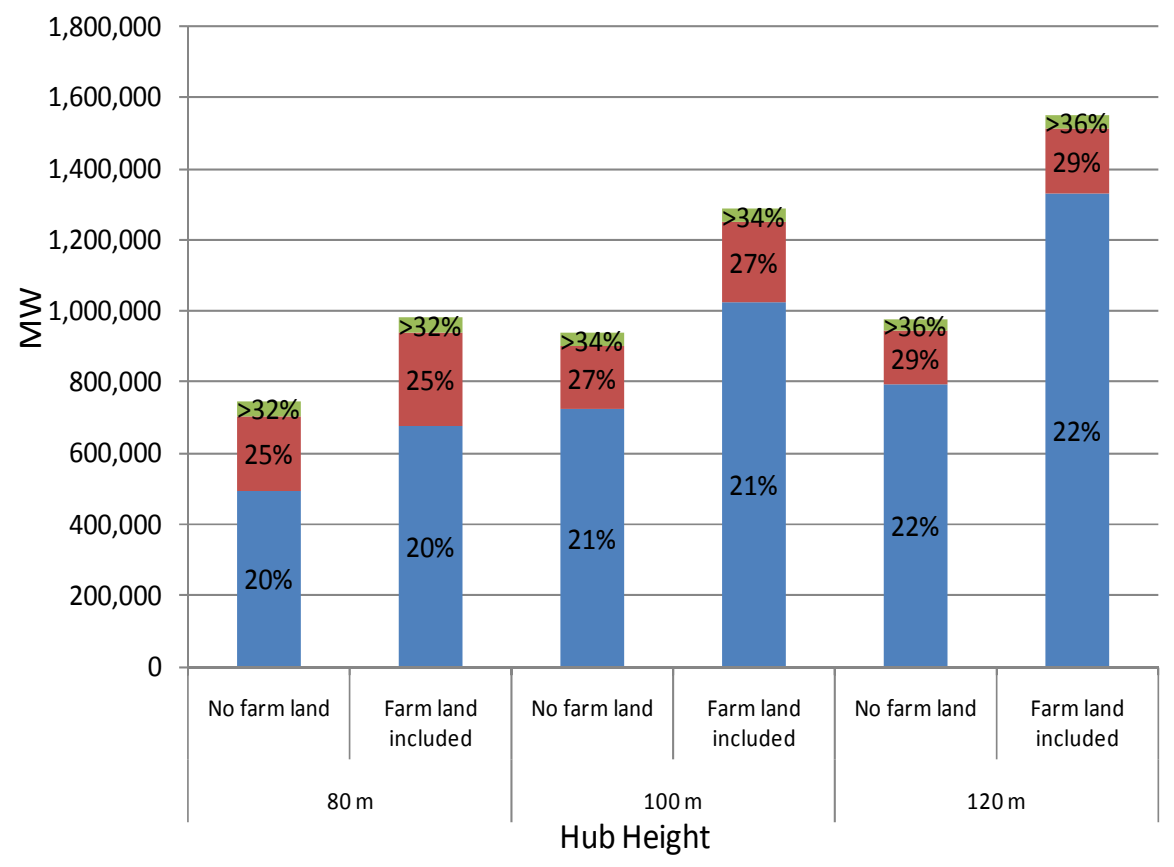

Figure ES 2. On-Shore Developable Wind Potential in India 
It is unlikely that all of the wind potential identified will be developed. The land requirement for developing 200,000 MW (which is about 20 times the current installed capacity) will be about 40,000 square $\mathrm{km}$ (based on a norm of $5 \mathrm{MW} /$ square $\mathrm{km}$ ), about $1.2 \%$ of the total land mass of India. Out of this land requirement, only $3 \%$ is the actual footprint of the wind farm (primarily due to towers and roads) and the rest of the land can be used for other purposes (Denholm, P. et al. 2009). Hence the actual land footprint of developing 200,000 MW of wind power will be about 1,200 square $\mathrm{km}$ (about $0.04 \%$ of the total land mass of India).

Using the norms specified by the Central Electricity Regulatory Commission (CERC), Figure ES 4shows the estimated wind potential at various levels of levelized tariffs. Based on CERC norms, approximately $200 \mathrm{GW}$ of wind potential is available at a levelized tariff of Rs. $5 / \mathrm{kWh}$ or less at all three hub-heights and both farmland inclusion scenarios. At 120m hub-height (minimum capacity factor of 22 percent), the "all farmland included" scenario yields approximately 1,000 $\mathrm{GW}$ of wind potential at Rs. 6/kWh or less. At least $18 \mathrm{GW}$ of wind energy potential can be exploited today at less than Rs. $4 / \mathrm{kWh}$ at all three hub-heights and under both farmland inclusion scenarios.

It is necessary to note that the estimates presented here regarding yields and the extent of land most suitable for wind power development in India are not detailed enough to determine sites for an actual wind generation facility or predict its exact output. These estimates are however appropriate for use in high-level policy-making; estimates based on methodologies similar to the one used here serve as the basis for policy development and long-term power sector planning purposes in the U.S., China, and the European Union.

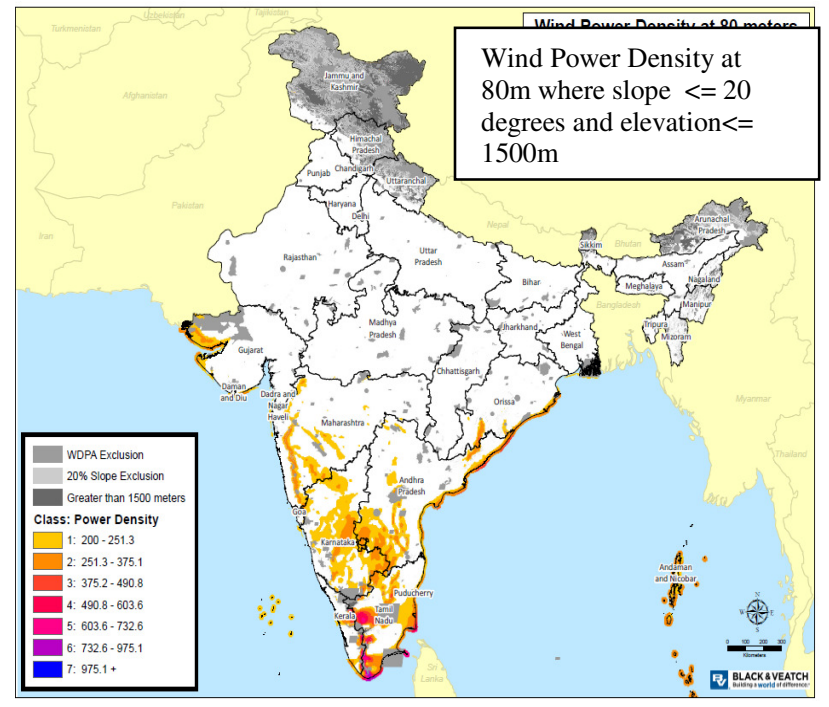

Figure ES 3. Wind Power Density at $80 \mathrm{~m}$

Preliminary assessment of seasonal patterns in wind speed (which is highly correlated to wind generation) and electricity demand suggests that wind generation in the South and the West (which peaks during late summer and monsoon) correlates well with demand in the North which is higher during this period compared to the other regions. As seen in Figure ES 5, wind speed in the South ramps up steadily from 7 am through 10 am, stays more or less constant until 6 pm, and tapers off later in the day. In the West, the peak wind speeds occur during later afternoon and 
evening. These time periods are also typical peak demand periods in most locations, as the temperature and corresponding cooling load ramps up throughout the day reaching maximum demand during late afternoon and evening. In other words, the diurnal variation of wind energy availability appears to have a substantial coincidence with the diurnal variation in demand.

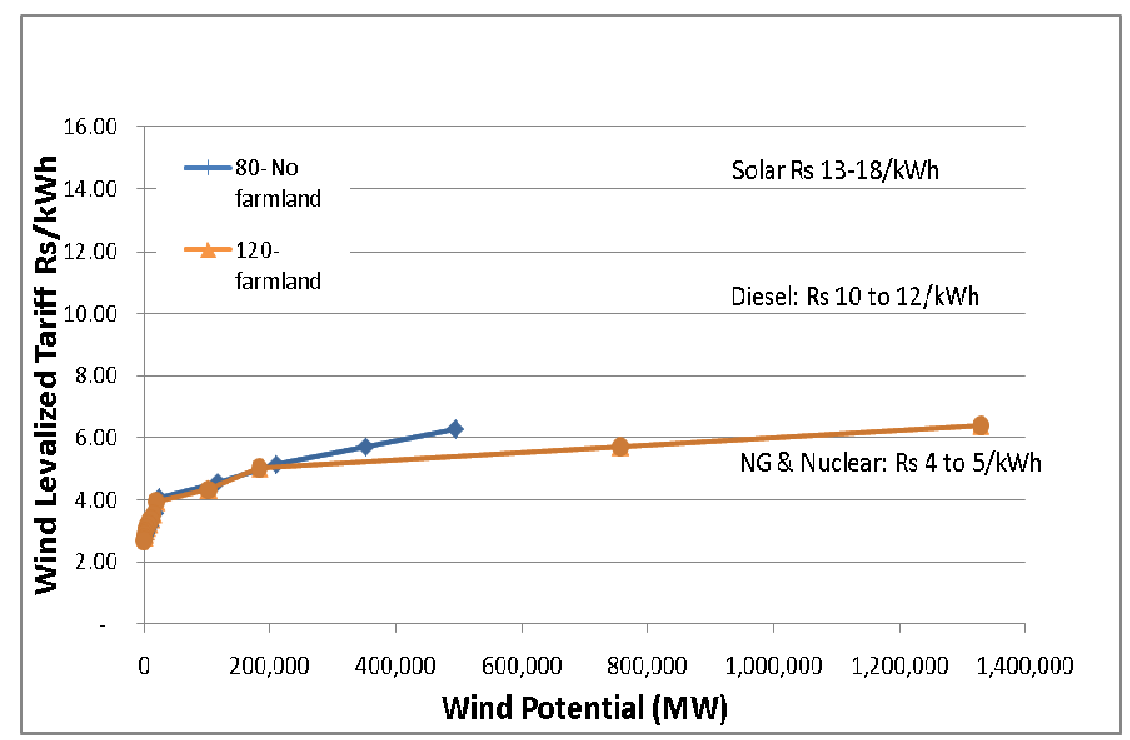

Figure ES 4. Available Wind Potential at Different Levelized Tariffs

Note:

- Prices for solar projects selected via competitive bidding in India are Rs 11-12/kWh

- Levelized tariff for wind power is lower for projects with higher capacity factors
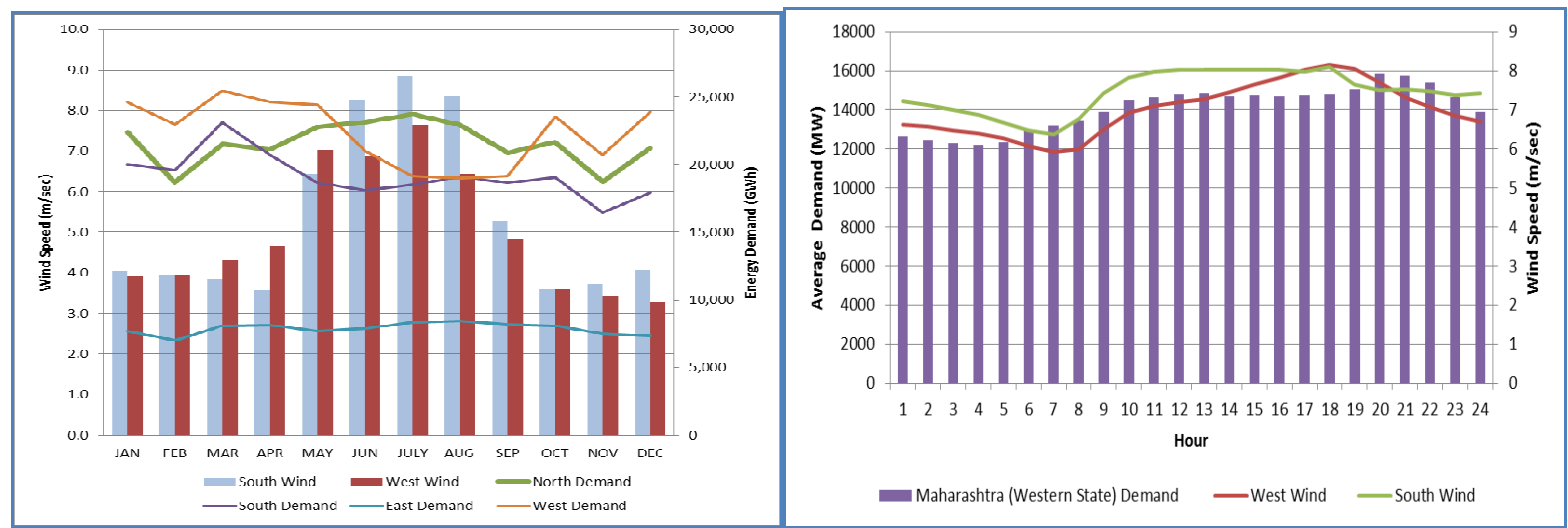

Figure ES 5. Temporal Patterns in Wind Generation and Electricity Demand ${ }^{4}$

${ }^{4}$ Source: Wind speed data - CWET (2010). Electricity demand data - CEA (2011). See section 5 for more details. 


\section{Implications and Future Work}

Our findings suggest that the availability of a developable wind resource is not a constraint for wind to play a major role in India's electricity future. This is in sharp contrast with the earlier official estimate of the potential, which, if fully exploited would have provided only about four percent of electricity demand (in energy terms) in 2022.

The technical feasibility of integrating large quantities of wind energy needs to be assessed systematically. However, experience from operation of existing power systems in such places as Denmark and Germany and several studies, have indicated the techno-economic feasibility of such integration (Milligan, M et al. 2009 and Wiser, et al., 2011). Given effective planning, policies, and programs, wind energy can be a core component of India's affordable, reliable, and clean energy portfolio. 


\section{Background and Motivation}

Electricity demand in India is expected to grow rapidly from $813 \mathrm{GWh}$ in 2007-08 to 2,104 GWh in 2020 for a GDP growth rate scenario of $8 \%$ per year (Planning Commission, Government of India (GOI), 2011). ${ }^{5}$ Current planning efforts call for the majority of this demand to be met by thermal power plants (i.e. coal and nuclear).

Historically, electricity demand has consistently outpaced electricity supply, leading to severe electricity shortages. Actual supply capacity additions have been consistently lower than the targets set by the government (Sathaye et al., 2010). As per the $11^{\text {th }}$ five-year plan, approximately $80 \mathrm{GW}$ of new coal capacity was expected to come online by 2012; to date only $50 \mathrm{GW}$ of that capacity has been constructed. Further, progress was slow in providing fuel for much of the coal capacity that was installed in 2010-11, suggesting that the capacity factors may be significantly lower than expected.

Alternative clean energy options, such as renewable energy (RE) and energy efficiency (EE), meet not only the environmental and energy security objectives, but also can play a crucial role in reducing chronic power shortages. Both $\mathrm{RE}$ and $\mathrm{EE}$ also can be deployed far more rapidly than conventional large-scale thermal power plants.

Wind energy is one of the cheapest forms of RE available, which partially explains why it accounts for the largest portion of RE installed capacity in the world, with 14,158 MW installed in India and 198,000 MW installed worldwide. ${ }^{6}$ Wind energy costs in India are typically less than one-half that of solar and are comparable to those of nuclear and natural gas-based plants. Consequently, wind is a very promising additional option to meet electricity shortages, at least in the short to medium term. ${ }^{7}$

The official estimate of wind energy potential in India by the Center for Wind Energy Technologies (CWET) is $49 \mathrm{GW}$ at a hub height of 50m (CWET, 2010) which is equivalent to only $4 \%$ of electricity needs in 2022. Based on these potential estimates, most studies on India's energy future have predicted only a limited role for wind energy. (See for example, Sargsyan, G. et al. (2010) (ESMAP report)., McKinsey (2008), and Planning Commission (2011).)

In contrast, two recent studies have indicated a much higher wind energy potential in India. Xi Lu et al. (2010) and Jami Hossain et al. (2011) find that on-shore developable wind energy potential ( $>20 \%$ capacity factor) in India is about $1,300 \mathrm{GW}$ and $2,076 \mathrm{GW}$, respectively estimated at hub heights of greater than or equal to $80 \mathrm{~m}$, the typical height of new wind turbines. These results are intriguing, but the studies' parameters limit their usefulness to Indian policy makers.

In Table 1, the country-specific wind potential estimated by Xi Lu et al. is shown. Note that Xi Lu et al. (2010) focused on global wind energy potential, so their assessment does not take into

\footnotetext{
${ }^{5}$ These estimates reflect electricity demand at the bus bar, which is equivalent to electricity generation requirements.

${ }^{6}$ Source: Indian Wind Energy Association -http://www.inwea.org/. REN 21. Renewables 2011. Global Status Report ,http://www.ren21.net/Portals/97/documents/GSR/GSR2011_Master18.pdf

${ }^{7}$ Based on the cost and operating norms specified by the Central Electricity Regulatory Commission (CERC) and discussed in detail in section 3.
} 
account some details important to India, including the geographic distribution of the wind energy potential within India and variations in the quality of its wind resource.

Table 1. Country-Specific Wind Potential

\begin{tabular}{|c|c|c|c|c|}
\hline Country & On Shore (MW) & Off Shore (MW) & On Shore (TWh) & Off Shore (TWh) \\
\hline Russia & $54,794,521$ & $10,502,283$ & 120,000 & 23,000 \\
\hline Canada & $35,616,438$ & $9,589,041$ & 78,000 & 21,000 \\
\hline U.S. & $33,789,954$ & $6,392,694$ & 74,000 & 14,000 \\
\hline China & $17,808,219$ & $2,100,457$ & 39,000 & 4,600 \\
\hline U.K. & $2,009,132$ & $2,831,050$ & 4,400 & 6,200 \\
\hline Germany & $1,461,187$ & 429,224 & 3,200 & 940 \\
\hline India & $1,324,201$ & 502,283 & 2,900 & 1,100 \\
\hline Japan & 260,274 & $1,232,877$ & 570 & 2,700 \\
\hline S. Korea & 59,361 & 452,055 & 130 & 990 \\
\hline Italy & 114,155 & 73,059 & 250 & 160 \\
\hline
\end{tabular}

The assessment by Hossain et al. (2011) focuses on India and analyzes the distribution of the quality of the wind resource. As identified by the authors, some key areas need further improvement including:

A They do not excluded certain key areas which are typically excluded from wind energy potential estimates because of practical difficulties, such as land on which the slope is greater than 20 degrees and elevation greater than 1500 meters. As a result, their estimate of wind potential is likely to be far greater than what could be achievable.

A They estimate wind power potential at a hub height of $80 \mathrm{~m}$ whereas wind turbines with hub heights of $100 \mathrm{~m}$ are becoming increasingly common and wind turbines with hub heights of $120 \mathrm{~m}$ are commercially available. An assessment of wind power potential at these heights will lead to a higher potential estimate than that at $80 \mathrm{~m}$.

A They do not estimate the cost of wind power in terms of the quality of the wind resource in order to compare it with other competing conventional and non-conventional options.

This wind potential study addresses the limitations discussed above.

Countries such as the U.S. and China have recently reassessed their wind energy potential and have found much higher potential. The estimate in China by China Meteorological Association (CMA) and in the U.S. by the National Renewable Energy Laboratory (NREL) increased about $800 \%$ and $400 \%$ respectively, as shown in Figure 1. Results of Wind Potential Reassessments in US and China

A systematic reassessment of two main aspects of wind energy production, considered by Xi Lu et al. (2010) and Hossain et al. (2011), might suggest that India's wind energy potential is higher than currently believed. Those aspects are 1) the rapidly improving wind turbine technology that allows better extraction of energy from wind and 2) the amount of available land suitable for wind farms. 


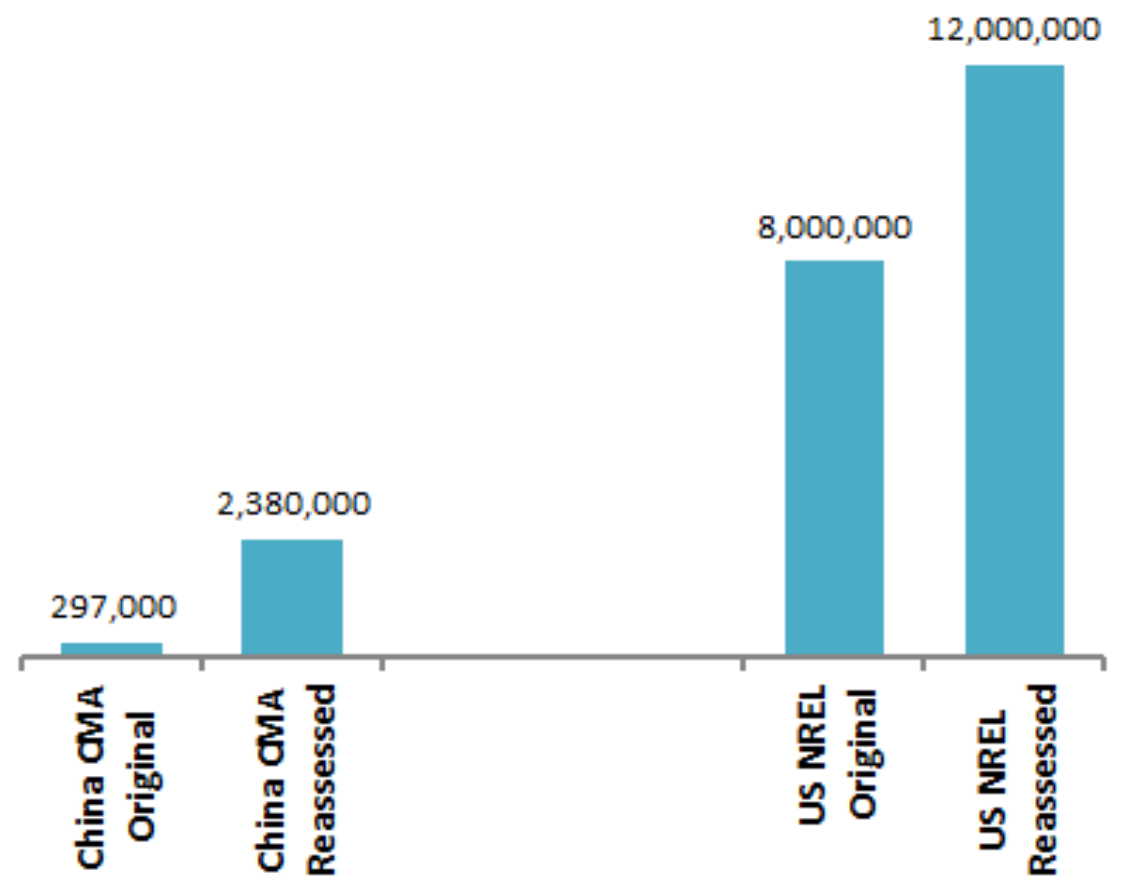

Figure 1. Results of Wind Potential Reassessments in US and China

US Original: Described in Black \& Veatch, "20 Percent Wind Energy Penetration in the United States: A Technical Analysis of the Energy Resource." Retrieved 7 August, 2011 from: http://www.20percentwind.org/Black_Veatch_20_Percent_Report.pdf. US reassessed -described in Elliott et al., 2010. New Wind Maps and Resource Potential Estimates for the United States. Retrieved from: http://www.nrel.gov/docs/fy11osti/50439.pdf.

China original and reassessed based on studies by China Meteorological Association (CMA) described in Li Junfeng et al., 2010 China Wind Power Outlook, October 2010, downloaded on 27/06/2011 from http://www.gwec.net/fileadmin/documents/test2/wind\%20report0919.pdf

From a technology perspective, the average nameplate capacity of wind turbines deployed in the world has been growing steadily over the last decade. For example, Wiser and Bollinger (2010) find that the average capacity of installed turbines in the U.S., which was about $0.8 \mathrm{MW}$ in 2000, more than doubled to about 1.74 MW by 2009. Various state-of-the-art installations in the U.S., EU, and China consist of turbines with capacities greater than $3 \mathrm{MW}$ and as high as $7 \mathrm{MW}{ }^{8}$ Ongoing research in EU suggests that $+10 \mathrm{MW}$ capacity wind turbines are feasible.

In addition to the capacity of the wind turbine, the average hub-height and rotor diameter of wind turbines has been growing steadily. ${ }^{9}$ Wiser and Bollinger (2010) report that the average hubheight and rotor diameter in the U.S. increased from about $60 \mathrm{~m}$ in 2000 to about $80 \mathrm{~m}$ in 2009.

\footnotetext{
${ }^{8}$ See, for example http://cordis.europa.eu/fetch?CALLER=FP7_PROJ_EN\&ACTION=D\&DOC=20\&CAT=PROJ\&QUERY=012309cd0ba0 :677b:3e409c80\&RCN=90994

${ }^{9}$ Higher hub-height allows wind turbines to exploit better quality wind resources at higher altitudes and larger rotor diameters allows wind turbines to sweep substantially larger areas thereby generating more energy.
} 
Better project planning and development have also led to steadily growing sizes of wind-farms and higher capacity factors. For example, Wiser and Bollinger (2010) find the average capacity factors in the U.S. have grown from about $25 \%$ to $30 \%$ over the last decade.

As for land availability, it is critical to systematically identify the ways high quality wind sites (e.g. with wind power density $>200 \mathrm{~W} / \mathrm{m} 2$ ) are being used and whether they are suitable for wind-farm development. In the 2010 Indian Wind Atlas, the authors, based on their expert judgment, state, "On a conservative consideration, a fraction of $2 \%$ land availability for all states except Himalayan states, Northeastern states and Andaman and Nicobar islands has been assumed for installable potential estimation. In Himalayan states, Northeastern states and Andaman and Nicobar islands, it is assumed to be 0.5\%. However, the potential will change as per the real land availability in each state" [emphasis added]. In contrast, this study uses a GISbased approach for excluding land that is not suitable for wind farm development using such industry-standard criteria as slope of land, altitude of land, water-bodies, and urban/rural use in a systematic, transparent, and easily replicable manner.

In this study, we estimate the developable wind energy potential in India taking into account both new efficient wind technology and several constraints, including land availability, terrain, and the quality of wind power. We assess the geographic distribution of the wind power within India as well as the distribution of wind energy potential in terms of the quality of the resource. We estimate the cost of wind energy and compare it with other supply-side options. Further, we undertake a preliminary assessment of the diurnal and seasonal variation of wind power and its correlation with electricity loads in India to provide insights into the role the wind energy can play in meeting electricity demand in India.

It is important to note that this assessment of wind potential is a high-level assessment and does not identify investment-grade locations for siting actual wind farms. Nor are the energy generation estimates developed in this assessment actual forecasts of energy production for existing wind farms. For investment-grade decisions, it is necessary to make actual measurement of wind data for a sustained period, supplemented with on-the-ground verification of relevant land features.

In Section 3 we describe the data and methodologies used in this study for estimating wind energy potential and compare it to the ones used by previous studies. In Section 4 we present our findings of the wind energy potential. In Section 4 we also present results related to the geographic distribution of this potential and the cost of developing this potential. In Section 5 we undertake a preliminary assessment of the role wind energy can plan given its seasonal and diurnal variation. In Section 6 we summarize our findings and discuss their implications for clean energy development in India. 


\section{Methodology}

In this section we describe the key data sources used in this analysis, the criteria and rationale for the selection of data sources, and the analytical steps used to estimate the technical potential for wind energy in India. In Figure 2, an overview of the methodology is presented. The methodology consists of four key steps - development of long-term temporal and spatial weather regimes over the Indian sub-continent, including meteorological parameters such as wind patterns, temperature, humidity, and others; development of wind power density and wind speed estimates at the required resolution level (e.g. 5-square-kilometer cell); application of land availability constraints to identify land suitable for wind power deployment; and mathematical calculation of wind energy that can be extracted from the land thus identified.

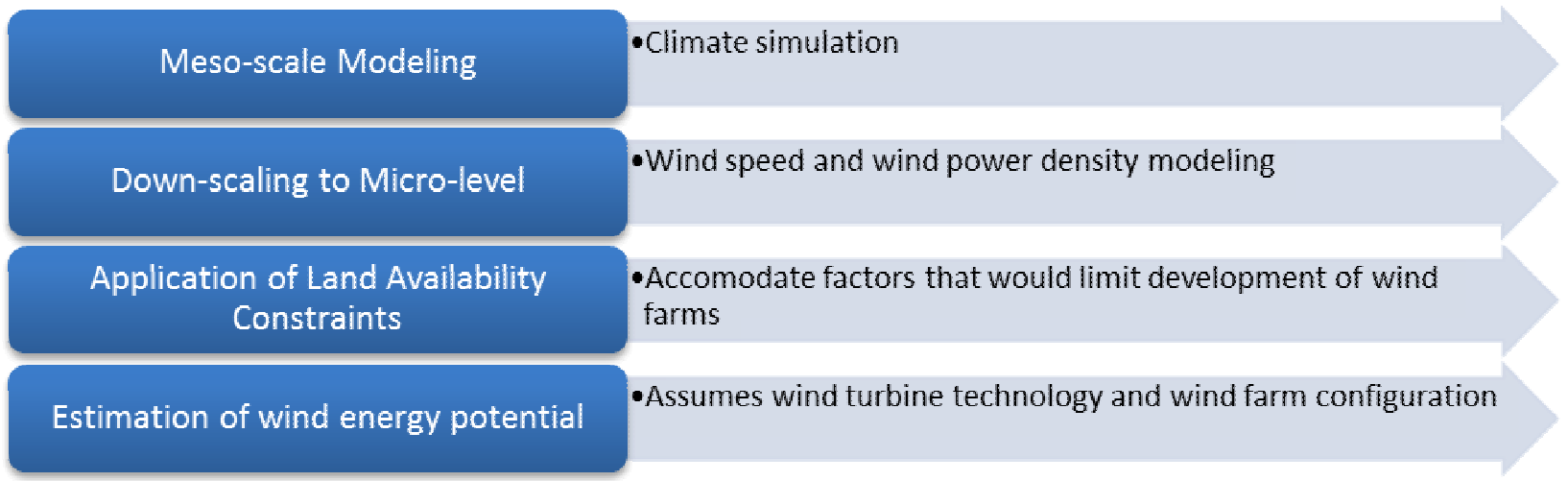

Figure 2 Overview of Methodology

\subsection{Data Sources}

The analysis presented here was largely conducted using Geographic Information System (GIS). Various types of datasets were evaluated using criteria such as format (i.e. compatibility with GIS systems and ease of use), quality of the data, and cost. The analysis presented here used offthe-shelf data, some of which was bought from a commercial vendor and the rest from publicly available databases.

\subsubsection{Wind Power Density and Wind Speed Data}

The fundamental data needed to estimate wind energy potential for any geographic region consists of wind speed and wind power density - preferably at altitudes comparable to the hubheights of the wind turbines that are likely to be installed and at a sufficiently high resolution level (both temporally and spatially) to ensure robustness of the estimates.

Ideally, this data should be measured directly by installing instruments (e.g. anemometers, etc.) at a sufficiently large number of locations for a sufficiently long period of time to ensure that the geographic area under consideration is adequately represented and the variability across seasons is accounted for.

Such data for India does not exist in either sufficient quantity or in an easily accessible form. Hence, four sources of wind data were reviewed: the U.S. National Aeronautics and Space Administration (NASA); 3Tier; AWS True Power; and the Centre for Wind Energy Technology 
(CWET). A summary of the key characteristics of data from each source is summarized in Table 2.

The spatial resolution of the NASA dataset was considered to be too large for the type of assessment conducted in this analysis and hence, was not selected. The resolution and quality of 3Tier, AWS True Power, and CWET data appears to be similarly appropriate for this high-level analysis. However, CWET data is not currently available in the needed GIS-compatible format. Data from AWS True Power is of the highest resolution but is substantially more expensive than that from 3Tier. Given the budget constraints and the comparable quality of data from 3Tier and AWS True Power, data from 3Tier was selected and procured for this analysis.

Table 2: Key Characteristics of Wind Datasets

\begin{tabular}{|c|c|c|c|c|c|}
\hline \multirow{2}{*}{ Source } & \multirow{2}{*}{ Location } & \multirow{2}{*}{ Resolution } & \multicolumn{3}{|c|}{ Typical Uses of Data } \\
\cline { 4 - 6 } & & $\begin{array}{c}\text { Strategic } \\
\text { Planning }\end{array}$ & $\begin{array}{c}\text { Preliminary } \\
\text { Feasibility Study }\end{array}$ & $\begin{array}{c}\text { Bankable Resource } \\
\text { Assessment }^{10}\end{array}$ \\
\hline NASA & $\begin{array}{c}\text { Internationa } \\
\text { I }\end{array}$ & $100 \mathrm{~km}$ & No & No & No \\
\hline 3Tier & USA & $3.6 \mathrm{~km}$ & Yes & Yes & No \\
\hline AWS True Power & USA & $200 \mathrm{~m}-1 \mathrm{~km}$ & Yes & Yes & No \\
\hline CWET & India & $5 \mathrm{~km}$ & Yes & Yes & No \\
\hline
\end{tabular}

3Tier's data used in this analysis is developed using a mesoscale model called Weather Research and Forecasting (WRF). WRF is a numerical weather prediction system designed to serve both operational forecasting and atmospheric research needs and is suitable for a broad spectrum of applications across scales ranging from a few meters to thousands of kilometers. ${ }^{12}$

3Tier data were validated against surface observations from the National Centers for Environmental Prediction (NCEP) network, which includes data from 1975 to the near present collected from moving ships, fixed ships, and both moored and drifting buoys. The collected data includes observations of cloud and wave behavior, surface and sea level pressure, air and surface temperature, dew point temperature, precipitation, and wind direction and speed. ${ }^{13}$ The validation report focusing on South Asia (including India) shows an overall bias of $0.19 \mathrm{~m} / \mathrm{s}$ and a root mean square error of $0.69 \mathrm{~m} / \mathrm{s}$ when compared to 24 meteorological stations in the area. For the high-level analysis presented here, these levels of bias and error are reasonable.

\subsubsection{Land Suitability Data}

Land use and terrain data was used to eliminate geographical areas not suitable for wind developments. Multiple databases with land use and elevation data were evaluated for resolution, format, quality, and ease of use. However, only one database was identified for protected areas.

\footnotetext{
${ }^{10}$ Minimum requirement is an independent $3^{\text {rd }}$ party wind resource assessment of at least a year of onsite data measurement, long term reference, wind flow model, loss estimates and uncertainty analysis.

${ }^{11}$ Wind data is not yet in GIS format.

${ }^{12}$ WRF has been a collaborative partnership of various US institutions, principally among the National Center for Atmospheric Research (NCAR), the National Oceanic and Atmospheric Administration's National Centers for Environmental Prediction (NCEP and its Forecast Systems Laboratory (FSL), the Air Force Weather Agency (AFWA), the Naval Research Laboratory, the University of Oklahoma, and the Federal Aviation Administration (FAA). For more details on WRF, see - http://www.wrf-model.org/index.php.

${ }^{13}$ http://www.3tier.com/en/support/wind-prospecting-tools/what-were-3tiers-data-validation-proceduresprospecting/
} 
Three sources of land use data were evaluated: GlobCover, Digital Chart of the World (DCW), and Center for International Earth Science Information Network (CIESIN). The sources vary in terms of both quality of the data and resolution. See Table 3. DCW data is relatively old, of low quality, and incomplete. No details were available about the vintage of the CIESIN dataset. Both datasets were rejected for this analysis.

GlobCover data, which was selected for this analysis, is of a relatively recent vintage, has a very high spatial resolution, and classifies land into categories relevant to the analysis. ${ }^{14}$ The GlobCover project was launched in 2004 as an initiative of the European Space Agency (ESA), and has since evolved into an international collaboration among several global agencies. GlobCover produced a global land-cover map, using as the main source of data the fineresolution $(0.3 \mathrm{~km})$ mode data acquired over the full year of 2005 from the MERIS sensor onboard ENVISAT satellite.

The validation approach for GlobCover data consisted of the creation of a dataset of validation sites that could be used to validate any new land cover map. The sites selected are not associated with any specific land cover map and retain statistical rigor when used on a variety of maps. The actual validation uses high spatial resolution satellite image data. International remote sensing experts interpret the local land cover characteristics and provide data for the statistical assessment of map accuracies.

Table 3: Key Characteristics of Land Use Datasets

\begin{tabular}{|c|c|c|c|c|}
\hline Source & $\begin{array}{c}\text { Spatial } \\
\text { Resolution }\end{array}$ & $\begin{array}{c}\text { Types of Data } \\
\text { Available }\end{array}$ & Root Data & Date \\
\hline GlobCover & $0.3 \mathrm{~km}$ & $\begin{array}{c}\text { Land Cover (including } \\
\text { water, urban areas) }\end{array}$ & ENVISAT MERIS Satellite & $\begin{array}{c}12 / 2004 \\
\text { to } \\
6 / 2006\end{array}$ \\
\hline $\begin{array}{c}\text { Digital Chart of } \\
\text { the World (DCW) }\end{array}$ & ${\mathrm{N} / \mathrm{A}^{15}}^{15}$ & $\begin{array}{c}\text { Water, Urban Areas, } \\
\text { Transportation, } \\
\text { Utility lines, Land } \\
\text { Cover }\end{array}$ & $\begin{array}{c}\text { Digital Aeronautical Flight Information } \\
\text { File, USGS, Joint Operation Graphics } \\
\text { and Tactical Pilotage Charts }\end{array}$ & $1991 /$ \\
\hline $\begin{array}{c}\text { Center for } \\
\text { International } \\
\text { Earth Science } \\
\text { Information } \\
\text { Network (CEISIN) }\end{array}$ & $\begin{array}{c}\text { second ( 1 } \\
\mathrm{km} \text { ) }\end{array}$ & $\begin{array}{c}\text { Urban Areas, } \\
\text { Population Density }\end{array}$ & $\begin{array}{c}\text { Various sources including satellite data } \\
\text { from Moderate Resolution Imaging } \\
\text { Spectro-radiometer (MODIS) and } \\
\text { Satellite Pour I'Observation de la Terre } \\
\text { (SPOT) Image Vegetation sensor, and } \\
\text { NASA }\end{array}$ & Unknown \\
\hline
\end{tabular}

\footnotetext{
${ }^{14}$ http://www.gofc-gold.uni-jena.de/sites/globcover.php

${ }^{15}$ Vector data, resolution not applicable.

${ }^{16}$ http://earth-info.nga.mil/publications/specs/printed/89009/89009_DCW.pdf
} 
Each 0.3-square-kilometer cell in the GlobCover dataset is classified into one of 21 categories based on the United Nations Land Cover Classification System. SeeTable 4: GlobCover Land Use Categories. ${ }^{17}$ These 21 categories were further aggregated to create the eight land cover/land use categories that were ultimately used in this analysis.

Table 4: GlobCover Land Use Categories

\begin{tabular}{|c|c|}
\hline $\begin{array}{l}\text { Land Use/ Land } \\
\text { Cover }\end{array}$ & GlobCover Classification \\
\hline Bare & Bare areas \\
\hline Farmland & Mosaic cropland (50-70\%)/vegetation (grassland/shrub-land/forest) (20-50\%) \\
\hline \multirow{7}{*}{ Forest } & Closed (>40\%) broadleaved deciduous forest \\
\hline & Closed (>40\%) needle-leaved evergreen forest \\
\hline & Closed to open (>15\%) (broadleaved or needle-leaved, evergreen or deciduous) shrub-land \\
\hline & Closed to open (>15\%) broadleaved evergreen or semi-deciduous forest $(5 \mathrm{~m})$ \\
\hline & Closed to open (>15\%) mixed broadleaved and needle-leaved forest \\
\hline & Mosaic forest or shrub-land (50-70\%)/grassland (20-50\%) \\
\hline & Open (15-40\%) broadleaved deciduous forest/woodland \\
\hline Grassland & Mosaic grassland (50-70\%)/forest or shrub-land $(20-50 \%)$ \\
\hline \multirow{4}{*}{$\begin{array}{l}\text { Grassland/ } \\
\text { cultivated land }\end{array}$} & Closed to open (>15\%) herbaceous vegetation (grassland, savannas or lichens/mosses) \\
\hline & Mosaic vegetation (grassland/shrub-land/forest)(50\%-70\%)/cropland (20-50\%) \\
\hline & Rain-fed cropland \\
\hline & Sparse $(<15 \%)$ vegetation \\
\hline Snow/ice & Permanent snow and ice \\
\hline Urban & Artificial surfaces and associated areas (Urban areas $>50 \%$ ) \\
\hline \multirow{5}{*}{ Water Body } & Closed (>40\%) broadleaved forest or shrub-land permanently flooded - Saline or brackish water \\
\hline & $\begin{array}{l}\text { Closed to open (>15\%) broadleaved forest regularly flooded (semi-permanently or temporarily) } \\
\text { - Fresh or brackish water }\end{array}$ \\
\hline & $\begin{array}{l}\text { Closed to open (>15\%) grassland or woody vegetation on regularly flooded or waterlogged soil } \\
\text { - Fresh, brackish or saline water }\end{array}$ \\
\hline & Post-flooding or irrigated cropland (or aquatic) \\
\hline & Water bodies \\
\hline
\end{tabular}

\subsubsection{Terrain Data}

Four datasets that provided information on the altitude and slope of terrain were evaluated. These include Aster, Shuttle Radar Topography Mission (SRTM), GTopo30, and NOAA Globe. All four of the datasets have high resolution. (See Table 5.) However, only three - Aster, SRTM, and GTopo30 - had the appropriate GIS-compatible format.

GTopo30 was completed in 1996 after a three-year collaboration among international agencies. ${ }^{18}$ It is a global digital elevation model (DEM) with a horizontal grid spacing of 30 arc seconds (or approximately $1 \mathrm{~km}$ ) and is derived from several raster and vector sources of topographic

\footnotetext{
${ }^{17}$ http://www.fao.org/docrep/003/x0596e/x0596e00.htm

${ }^{18}$ The effort was led by staff of the U.S. Geological Survey's EROS Data Center (EDC) and several organizations including the National Aeronautics and Space Administration (NASA), the United Nations Environment Programme/Global Resource Information Database (UNEP/GRID), the U.S. Agency for International Development (USAID), the Instituto Nacional de Estadistica Geografica e Informatica (INEGI) of Mexico, the Geospatial Information Authority of Japan (GSI) Manaaki Whenua Landcare Research of New Zealand, and the Scientific Committee on Antarctic Research (SCAR).
} 
information. It is of a relatively older vintage and less accurate than the Aster and SRTM datasets. However, the authors of this analysis had previously attempted to use the Aster and SRTM datasets for high level analysis and had encountered significant problems in manipulating them. Consequently, it was decided to use GTopo30 for this analysis.19

Table 5: Key Characteristics of Terrain Datasets

\begin{tabular}{|l|l|l|l|l|}
\hline Source & $\begin{array}{l}\text { Spatial } \\
\text { Resolution }\end{array}$ & $\begin{array}{l}\text { Coverage } \\
\text { Area }\end{array}$ & Root Data & Notes \\
\hline Aster & $30 \mathrm{~m}$ & Global & NASA Satellite & $\begin{array}{l}\text { Highest quality, GIS compatible, } \\
\text { potentially difficult to obtain and } \\
\text { use }\end{array}$ \\
\hline $\begin{array}{l}\text { Shuttle Radar } \\
\text { Topography } \\
\text { Mission (SRTM) }\end{array}$ & $\begin{array}{l}3 \text { arc-seconds } \\
\text { (about } 90 \mathrm{~m})\end{array}$ & Global & NASA Satellite & $\begin{array}{l}\text { Most popular, GIS compatible, } \\
\text { difficult to use }\end{array}$ \\
\hline GTopo30 & $\begin{array}{l}30 \text { arc- } \\
\text { seconds } \\
\text { (about } 0.9 \\
\text { km) }\end{array}$ & Global & $\begin{array}{l}\text { Agency, Digital Chart of the } \\
\text { World and International } \\
\text { Imagery and the World }\end{array}$ & $\begin{array}{l}\text { Used in past analysis, GIS } \\
\text { compatible, easy to use, older } \\
\text { and less accurate }\end{array}$ \\
\hline NOAA Globe & $\begin{array}{l}30 \text { arc } \\
\text { seconds } \\
\text { (about } 1 \mathrm{~km})\end{array}$ & Global & $\begin{array}{l}\text { U.S. Department of } \\
\text { Defense/NASA Satellite }\end{array}$ & $\begin{array}{l}\text { Higher quality than GTop30, } \\
\text { format not clearly GIS } \\
\text { compatible }\end{array}$ \\
\hline
\end{tabular}

\subsubsection{Protected Areas Data}

The World Database of Protected Areas (WDPA) is a database created by the United Nations Environment Programme, World Conservation Monitoring Centre, and the International Union of Conservation of Nature's World Commission of Protected Areas. It is a worldwide database of protected areas, which are defined as clearly delimited geographical space, recognized, dedicated and managed through legal or other effective means to achieve the long-term conservation of nature with associated ecosystem services and cultural values. ${ }^{21}$ The database is updated and released annually in polygon format. The 2010 release was used for this analysis.

\subsection{Estimation of Technical Potential from Wind Power Density and Wind Speed}

Each 5-square-kilometer cell was assigned a wind class as defined by the U.S. National Renewable Energy Laboratory (NREL). ${ }^{22}$ These wind classes assume a hub-height of 50 meters. It should be noted that India's CERC has defined cost-related norms based on wind classes as defined by NREL.

The analysis presented here estimates wind potential at higher hub-heights - i.e. 80, 100, and 120 meters. Therefore it was necessary to extrapolate the NREL wind classes to those heights. The $1 / 7^{\text {th }}$ power law profile was used to do the extrapolation. For the extrapolation, a standard air density of $1.225 \mathrm{~kg} / \mathrm{m}^{3}$ was assumed. The Weibull shape parameter (i.e. $c$ in Equation 1) that is necessary for the extrapolation was estimated assuming a Weibull scale parameter (i.e. $\mathrm{k}$ in

\footnotetext{
${ }^{19}$ For more details, see - http://www1.gsi.go.jp/geowww/globalmap-gsi/gtopo30/gtopo30.html

${ }^{20}$ http://www1.gsi.go.jp/geowww/globalmap-gsi/gtopo30/README.html\#h17

${ }^{21}$ http://www.wdpa.org/

${ }^{22}$ D.L. Elliott, et al., "Wind Energy Resource Atlas of the United States", Pacific Northwest Laboratory for the U.S. Department of Energy, 1986
} 
Equation 1) of 2 (C.G. Justus, et al., 1977). In Equation 1, $\bar{V}$ refers to the wind speed (obtained from the 3Tier dataset), and $\Gamma$ represents the standard gamma function.

$$
\text { Equation 1: } c=\frac{\bar{V}}{\Gamma\left(1+\frac{1}{\mathrm{k}}\right)}
$$

For a $50 \mathrm{~m}$ hub-height, wind class 1 corresponds to wind power density ranging from $0 \mathrm{~W} / \mathrm{m}^{2}$ to $200 \mathrm{~W} / \mathrm{m}^{2}$. Extrapolating this range to higher hub-heights yields a range of $0-251.3 \mathrm{~W} / \mathrm{m}^{2}$ at 80 meters, $0-276.5 \mathrm{~W} / \mathrm{m}^{2}$ at 100 meters, and $0-299 \mathrm{~W} / \mathrm{m}^{2}$ at 120 meters.

Because the analysis presented here had assumed a minimum threshold of $200 \mathrm{~W} / \mathrm{m}^{2}$ for the wind power density for all hub-heights, it was necessary to develop one sub-class (1a) to account for the wind power density range of $200-251.3 \mathrm{~W} / \mathrm{m}^{2}$ at 80 meters. For the $100 \mathrm{~m}$ and $120 \mathrm{~m}$ hubheights, it was necessary to develop two sub-classes (1a and 1b) that could account for the a wind power density values falling in the range of $200-276.5 \mathrm{~W} / \mathrm{m}^{2}$ at $100 \mathrm{~m}$ heights, and $200-299$ $\mathrm{W} / \mathrm{m}^{2}$ at $120 \mathrm{~m}$. At $100 \mathrm{~m}$ heights, class $1 \mathrm{a}$ is defined for a range of $200-220 \mathrm{~W} / \mathrm{m}^{2}$ and class $1 \mathrm{~b}$ is defined as $220-276.5 \mathrm{~W} / \mathrm{m}^{2}$. At 120 meters, class 1 a is defined for a range of $200-237.9 \mathrm{~W} / \mathrm{m}^{2}$ and class $1 \mathrm{~b}$ is defined as $237.9-299 \mathrm{~W} / \mathrm{m}^{2}$. The definitions of wind classes, wind power density, wind speed ranges, and capacity factors at various hub-heights are presented in Table 6.

Each wind class was assigned a net capacity factor. The capacity factor was based on empirical data collected by Wiser and Bollinger (2010) for projects installed in the U.S. between 2005 and $2007 .{ }^{23}$ However, the data collected by LBNL did not assign capacity factors to the lower quality wind classes (i.e. below Class 2) for the hub-heights considered in this analysis. Assuming a typical turbine available currently on the market - Clipper C99 - capacity factors were estimated for sub-classes $1 \mathrm{a}$ and $1 \mathrm{~b}$. More advanced commercially available wind turbines such as GE's 1.6 XLE can operate at higher capacity factors in the lower wind class areas and will result into a higher wind generation potential estimate. Turbines considered advanced today are likely to become more common in the future and hence the wind potential in the future is likely to be higher than estimated by this analysis. Further, turbines with higher rotor diameter have shown to be more suitable for lower wind speeds and will lead to higher capacity factors than estimates in this analysis.

\footnotetext{
${ }^{23}$ Wiser, Ryan H. 2010, “Understanding Trends in Overall U.S. Wind Project Performance," WindPower 2010, pp. 10-
} 11. 
Table 6: Wind Power Class, Density, and Capacity Factors

\begin{tabular}{|c|c|c|c|c|c|c|c|c|c|c|c|}
\hline \multirow{2}{*}{$\begin{array}{c}\text { Wind } \\
\text { Power } \\
\text { Class }\end{array}$} & \multicolumn{2}{|c|}{$50 \mathrm{~m}$} & \multicolumn{3}{|c|}{$80 \mathrm{~m}$} & \multicolumn{3}{|c|}{$100 \mathrm{~m}$} & \multicolumn{3}{|c|}{$120 \mathrm{~m}$} \\
\hline & WPD & WS & $\mathrm{CF}$ & WPD & WS & CF & WPD & WS & CF & WPD & WS \\
\hline 1 & $0-200$ & $0-5.6$ & - & $0-200$ & $0-5.6$ & - & $0-200$ & $0-5.6$ & - & $0-200$ & $0-5.6$ \\
\hline $1 a$ & $N A$ & $N A$ & $20 \%$ & $200-251.3$ & $5.6-6.0$ & $20.0 \%$ & $200-220$ & $5.6-5.7$ & $20.0 \%$ & $200-237.9$ & 5.6-5.9 \\
\hline $1 b$ & $N A$ & $N A$ & $N A$ & $N A$ & $N A$ & $21.6 \%$ & $220-276.5$ & $5.7-6.2$ & $23.3 \%$ & 237.9-299 & 5.9-6.3 \\
\hline 2 & $200-300$ & $5.6-6.4$ & $25 \%$ & $\begin{array}{c}251.3- \\
375.1\end{array}$ & $6.0-6.9$ & $27.0 \%$ & 276.5-412.7 & $6.2-7.1$ & $29.0 \%$ & $299-446.3$ & 6.3-7.3 \\
\hline 3 & $300-400$ & $6.4-7.0$ & $32 \%$ & $\begin{array}{c}375.1- \\
490.8\end{array}$ & 6.9-7.5 & $34.0 \%$ & $412.7-540$ & 7.1-7.7 & $35.5 \%$ & 446.3-583.9 & 7.3-7.9 \\
\hline 4 & $400-500$ & $7.0-7.5$ & $36 \%$ & $\begin{array}{c}490.8- \\
603.6 \\
\end{array}$ & $7.5-8.0$ & $37.5 \%$ & $540-664.2$ & 7.7-8.3 & $39.0 \%$ & 583.9-718.2 & 7.9-8.5 \\
\hline 5 & $500-600$ & $7.5-8.0$ & $39 \%$ & $\begin{array}{c}603.6- \\
732.6\end{array}$ & $8.0-8.6$ & $40.5 \%$ & $664.2-806.1$ & 8.3-8.8 & $42.0 \%$ & $718.2-871.6$ & $8.5-9.1$ \\
\hline 6 & $600-800$ & $8.0-8.8$ & $42 \%$ & $\begin{array}{c}732.6- \\
975.1\end{array}$ & $8.6-9.4$ & $43.5 \%$ & $\begin{array}{c}806.1- \\
1,072.9\end{array}$ & $8.8-9.7$ & $45.0 \%$ & $\begin{array}{c}871.6- \\
1,160.1\end{array}$ & 9.1-10 \\
\hline
\end{tabular}

WPD $=$ Wind Power Density $\left(\mathrm{W} / \mathrm{m}^{2}\right)$

$\mathrm{WS}=$ Wind Speed $(\mathrm{m} / \mathrm{s})$

$\mathrm{CF}=$ Capacity Factor

\subsection{GIS Analysis}

Once each 5-square-kilometer cell in India was assigned a wind class at each of the three hubheights, they were separated according to their suitability for wind power development as identified using GIS data. The thresholds for exclusion and the sources of data used to establish them are summarized in Table 7.

Table 7: Land Types Unsuitable For Wind Power Development

\begin{tabular}{|l|l|l|}
\hline Parameter & Criteria for Exclusion & Data Source \\
\hline Terrain slope & Greater than 20 percent & GTopo30 \\
\hline Elevation & Greater than 1,500 m & GTopo30 \\
\hline Protected areas & 100 percent & WDPA \\
\hline Water bodies & 100 percent & GlobCover \\
\hline Urban areas & 100 percent & GlobCover \\
\hline Forests & 100 percent & GlobCover \\
\hline Snow/Ice & 100 percent & GlobCover \\
\hline Grassland & 100 percent & GlobCover \\
\hline Bare land & 0 percent & GlobCover \\
\hline Grassland/ cultivated land & 0 percent & GlobCover \\
\hline Farmland & Sensitivity analysis & GlobCover \\
\hline
\end{tabular}

As shown in Figure 3 and Figure 4, the GIS analysis was done in multiple steps as follows

1) Each $3.6 \mathrm{~km}$ by $3.6 \mathrm{~km}$ cell was assigned to a unique wind density bin (refer to Table 6 for definition of the bins)

2) $3.6 \mathrm{~km}$ by $3.6 \mathrm{~km}$ cells that were identified as protected areas, had slope above $20 \%$, had elevation above $1500 \mathrm{~m}$, or had WPD less than $200 \mathrm{~W} / \mathrm{m}^{2}$ were removed

3) Land cover layer was applied to the $3.6 \mathrm{~km}$ by $3.6 \mathrm{~km}$ cells remaining after step 2 
a) Each $3.6 \mathrm{~km}$ by $3.6 \mathrm{~km}$ cell remaining after step 2 contains 144 cells of $0.3 \mathrm{~km}$ by 0.3 $\mathrm{km}$ land use/land cover cells

b) Each $0.3 \mathrm{~km}$ by $0.3 \mathrm{~km}$ cell has two characteristics:

i) WPD bin classification; and

ii) Land use/land cover

c) $0.3 \mathrm{~km}$ by $0.3 \mathrm{~km}$ cells of land cover that are not suitable for wind power development were removed

d) Wind potential in all remaining $0.3 \mathrm{~km}$ by $0.3 \mathrm{~km}$ cells was added to produce the aggregate estimate at state and national levels

4) Data output from GIS was total area for each land cover layer grid with wind density bins

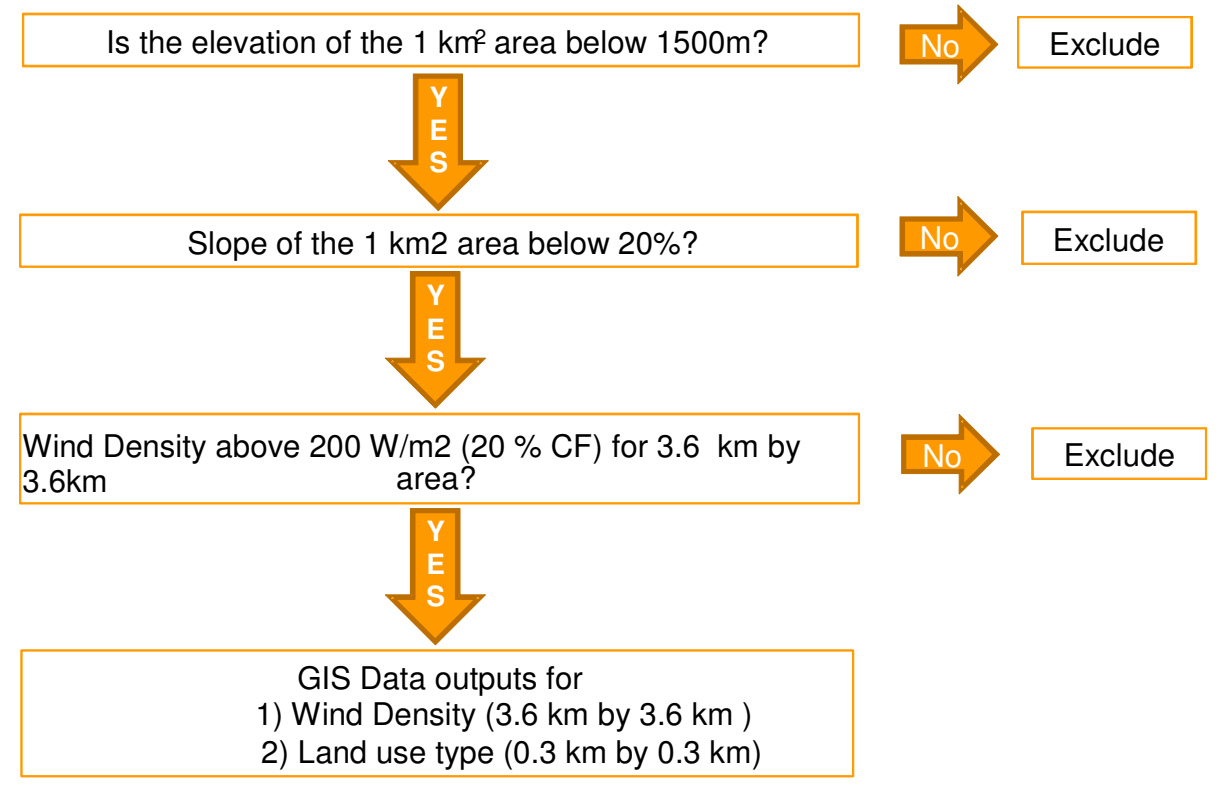

Figure 3: Steps of the GIS Analysis

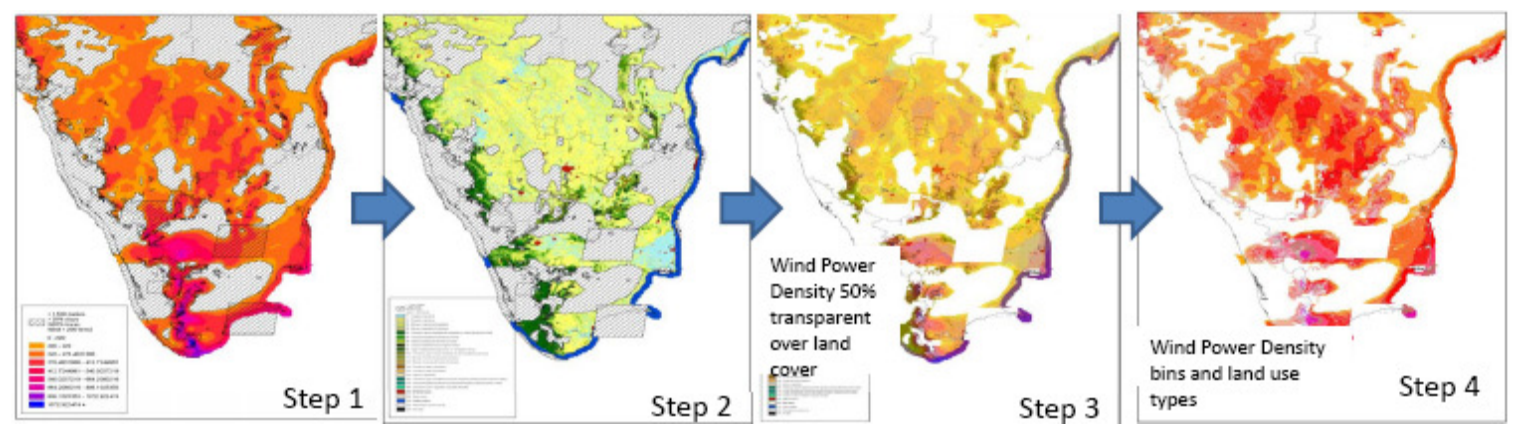

Figure 4: Results of the GIS Analysis 
This study assumed that $5 \mathrm{MW}$ of capacity can be developed in one square kilometer of land. This capacity density is based on a U.S. Department of Energy (U.S. DOE) theoretical estimate that 20 hectares are required per MW. The National Renewable Energy Laboratory (NREL) uses this value as well when conducting high-level potential estimates. ${ }^{24}$ NREL also has conducted empirical research on the land use requirements of wind power plants in the U.S. ${ }^{25}$ Data analyzed by NREL for 161 wind projects $20 \mathrm{MW}$ and larger show that average capacity density is $3.0 \pm 1.7 \mathrm{MW} / \mathrm{km}^{2}$. Some projects in the U.S. and Europe located in high-quality wind areas have achieved capacity densities above $11 \mathrm{MW} / \mathrm{km} .{ }^{2}$ CWET's potential estimate is based on the assumption of a capacity density of $9 \mathrm{MW} / \mathrm{km}^{2}$. A relatively conservative value of $5 \mathrm{MW} / \mathrm{km}^{2}$ was used for this analysis to be consistent with NREL methodology. Our potential estimate will almost be double if we use the assumption by CWET.

\footnotetext{
${ }^{24} \mathrm{http} / / /$ www.windpoweringamerica.gov/wind_maps.asp for Wind Resource Potential in United States; http://www.nrel.gov/international/pdfs/afg_pak_wind_june07.pdf for Wind Resource Assessment and mapping for Afghanistan and Pakistan

${ }^{25} \mathrm{http}: / /$ www.nrel.gov/docs/fy09osti/45834.pdf
} 


\section{Results}

Figure 5 shows developable on-shore wind potential at three different hub-heights and under two sensitivity scenarios - no farmland included and all farmland included. Under the "no farmland included" case, the total wind potential in India ranges from $748 \mathrm{GW}$ at $80 \mathrm{~m}$ hub-height (and minimum 20 percent capacity factor) to $976 \mathrm{GW}$ (and minimum 22 percent capacity factor). Under the "all farmland included" case the potential with a minimum capacity factor of 20 percent ranges from $984 \mathrm{GW}$ to 1,549 GW. As is seen in Figure 4, most of the wind energy potential is in the lower capacity wind energy sites. High quality wind energy sites alone, at $80 \mathrm{~m}$ hub-height with a minimum capacity factor of 25 percent, have a potential between $253 \mathrm{GW}$ (no farmland included) and $306 \mathrm{GW}$ (all farmland included)- more than five times the current official estimate.

Off-shore developable potential in India is about $237,964 \mathrm{MW}$ at $100 \mathrm{~m}$ hub-height with a minimum capacity factor of 21 percent. The wind tower structures and costs vary substantially as the depth of water in which these turbines are developed. Approximately, 78 percent of the developable off-shore potential is available at depths less than $30 \mathrm{~m}$.

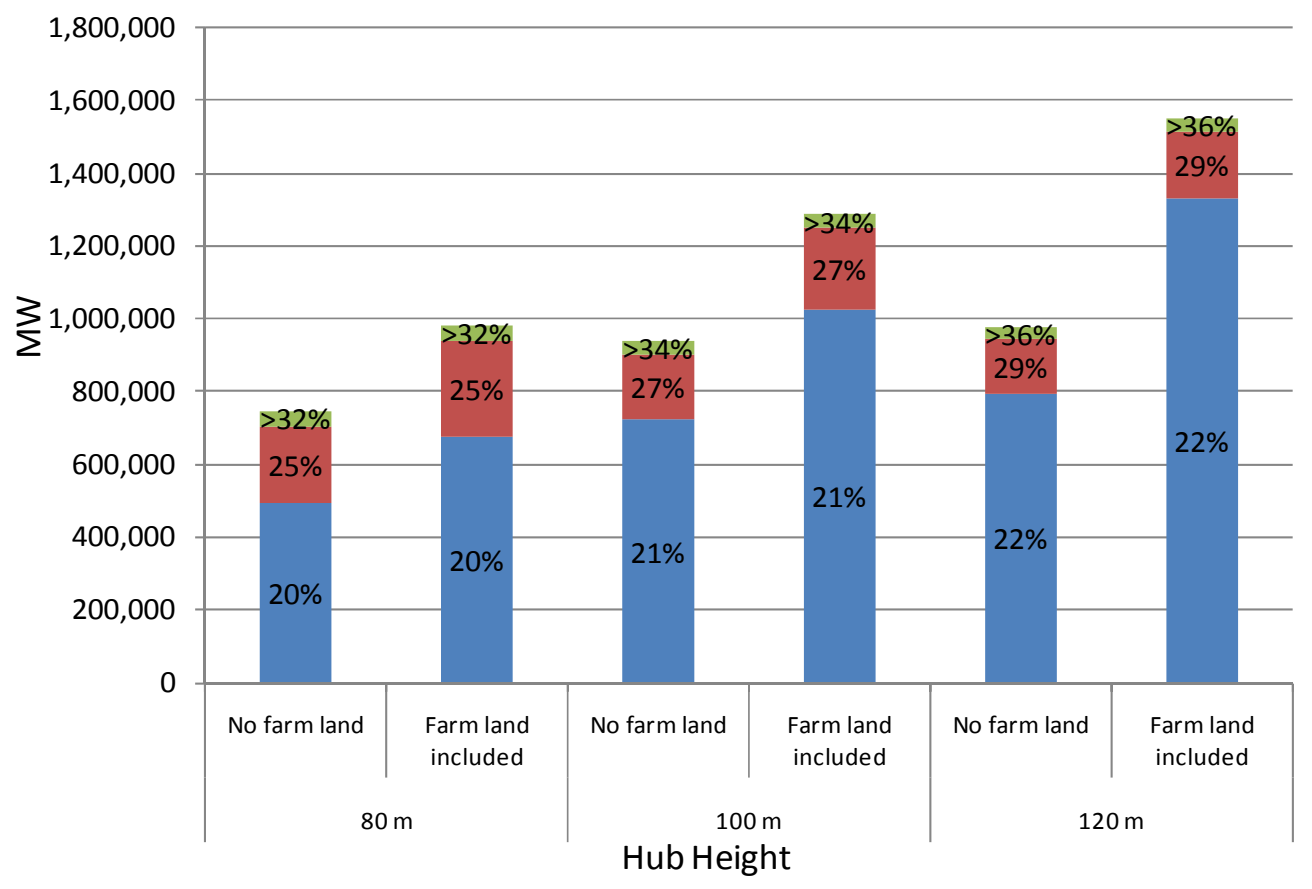

Figure 5: On-Shore Developable Wind Potential in India

The potential estimated in this analysis is more than 30 times that of the official Indian estimate published in the 2010 Indian Wind Energy Atlas, and is similar to the estimate by Xi Lu et al. (2009) and Hossain et al. (2011). The most likely reason for the large difference between the estimate in this analysis and the official Indian estimate is the difference in assumed land availability. CWET assumes (stating no justification) that only two percent of the total windy land will be available for wind power development (CWET, 2010). CWET does note that the potential will be higher if more land is considered available for wind power development. 
As seen from the map shown in Figure 6, more than 95 percent of the wind energy potential is concentrated in just five states in southern and western India - Tamil Nadu, Andhra Pradesh, Karnataka, Maharashtra, and Gujarat. Interestingly, the state with the overall largest resource is Karnataka while the state with largest best-quality resource is Tamil Nadu. From a cost-effective perspective, the full development of best-quality wind resources in Tamil Nadu - which already leads all states in installed wind capacity - would yield a capacity of $31 \mathrm{GW}$ at a $120 \mathrm{~m}$ hubheight and a minimum capacity factor of $36 \% .^{26}$ This is more than twice the total installed wind capacity in India. See Figure 6.

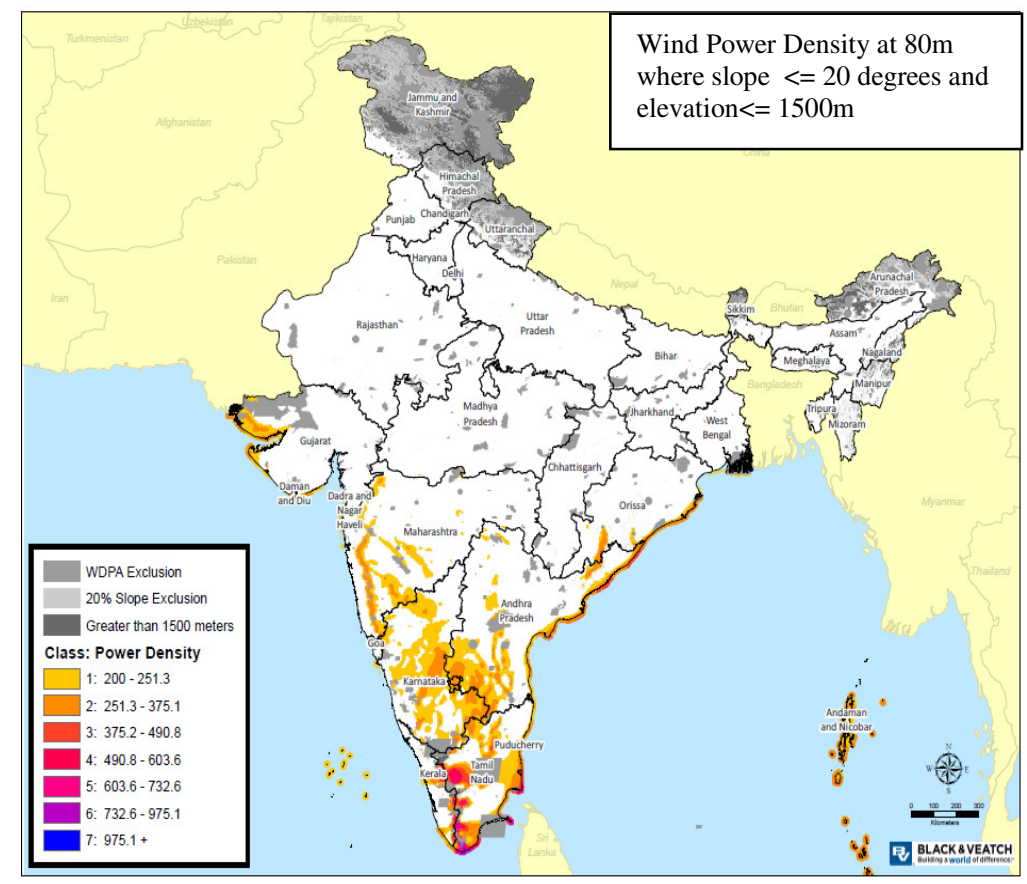

Figure 6. Wind Power Density at $80 \mathrm{~m}$

${ }^{26}$ Note: this would likely involve re-powering existing installations with more efficient technology. 


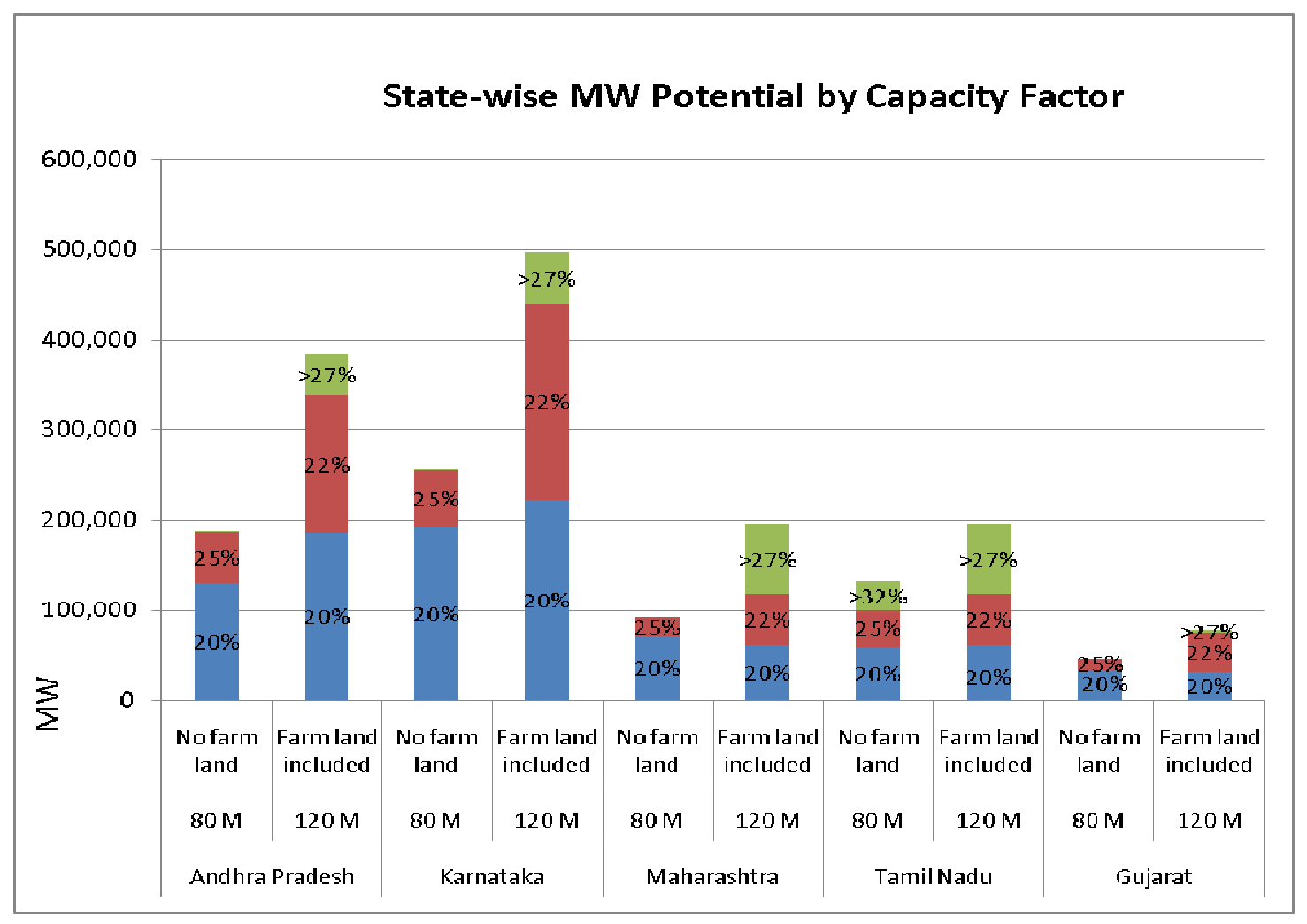

Figure 7: Wind Energy Potential for five states

It is necessary to note that the estimates presented here regarding yields and the extent of land most suitable for wind power development in India are not detailed enough to determine a site for an actual wind generation facility or predict its exact output. These estimates are however appropriate for use in high-level policy-making; estimates based on methodologies similar to the one used here serve as the basis for policy development and long-term power sector planning purposes in the U.S., China, and the European Union.

Using the norms specified by the CERC (see Table 8) for estimating the levelized tariff of wind power projects in India (CERC, 2009), the wind potential at various levels of levelized cost were estimated (See Figure 7: Wind Energy Potential for five states).

Table 8. Wind Power Levelized Tariff Assumptions Based on CERC norms ${ }^{27}$

\begin{tabular}{|l|r|l|r|}
\hline Debt: Equity Ratio & $70: 30$ & Aux consumption & $1 \%$ \\
\hline Capital Cost (Rs Cr/MW) at 50m & 5.15 & Loan tenure years & 10 \\
\hline O\&M Expenses (Rs Cr/MW/yr) & 0.065 & Depreciation rate & $7 \%$ \\
\hline O\&M Expenses (\% of capital cost) & $1.3 \%$ & Normative interest rate & $14 \%$ \\
\hline O\&M cost escalation & $5.72 \%$ & RoE (pre-tax) - first 10 years & $19 \%$ \\
\hline Useful life years & 25 & RoE (pre-tax) - after 10 years & $24 \%$ \\
\hline
\end{tabular}

\footnotetext{
${ }^{27}$ Note: Capital costs were adjusted upwards to include increased costs of higher hub heights based on 1) the relative share of the total cost of wind generators accounted for by the tower and the foundation and 2 ) the relationship between increase in hub heights and the increase in these cost components (based on Fingersh, L, 2006).
} 


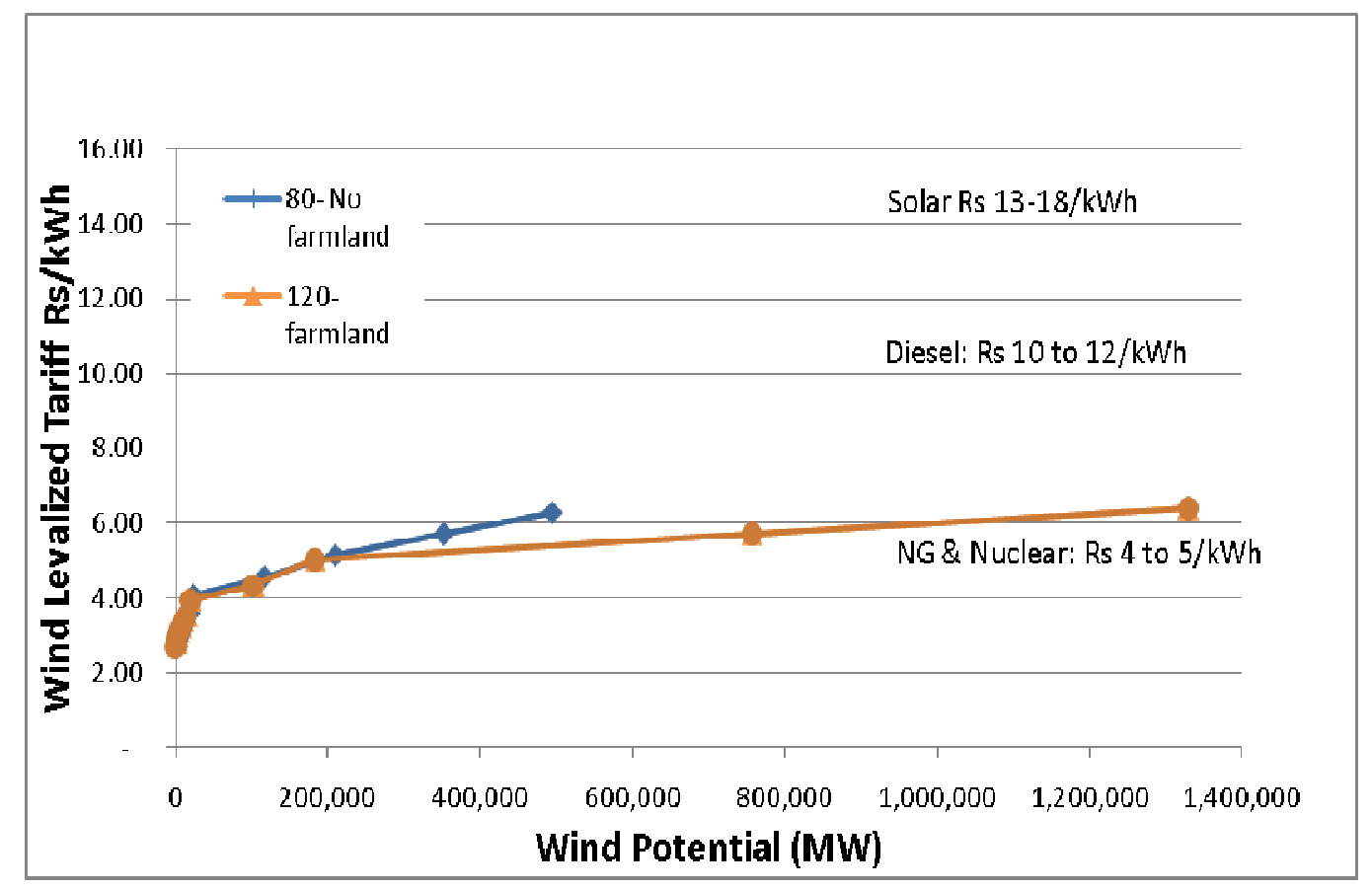

Figure 8: Levelized Cost Of Wind Potential

Note:

- Prices for solar projects selected via competitive bidding in India are Rs 11-12/kWh.

- Levelized tariff for wind power is lower for projects with higher capacity factor.

Based on CERC norms, approximately $200 \mathrm{GW}$ of wind potential is available at a levelized cost of Rs. 5/kWh, or less at all three hub-heights and both farmland inclusion sensitivity cases. Using a $120 \mathrm{~m}$ hub-height (minimum capacity factor of 22 percent) and "all farmland included" scenario, approximately $1,000 \mathrm{GW}$ of wind potential is available at Rs. $6 / \mathrm{kWh}$ or less. At least $18 \mathrm{GW}$ of wind energy potential can be developed today at less than Rs. $4 / \mathrm{kWh}$ at all three hubheights and under both farmland inclusion scenarios.

\section{POtential ROLE OF WIND IN THE INDIAN POWER SySteM}

In addition to wind power potential and the cost of its development, several other factors determine the potential role wind power can play in India's electricity system. These include the coincidence of wind generation with the seasonal and diurnal patterns in electricity demand, the degree of variability of wind generation and costs related to integrating wind in the system, and the proximity of high-quality wind sites to load centers.

A preliminary analysis of some of the coincidence of wind generation with the seasonal and diurnal patterns in electricity demand is presented here to provide insights into the role wind power might play in the India power system.

\subsection{Coincidence of Wind Generation with Seasonal Load Shapes at National and Regional Levels}

Figure 9 shows the typical seasonal pattern of wind speeds in the five states with highest wind potential (Andhra Pradesh, Karnataka, and Tamil Nadu in the South and Gujarat and 
Maharashtra in the West) and the seasonal pattern of electricity demand in the north, south, east, and west regions of India. ${ }^{28}$

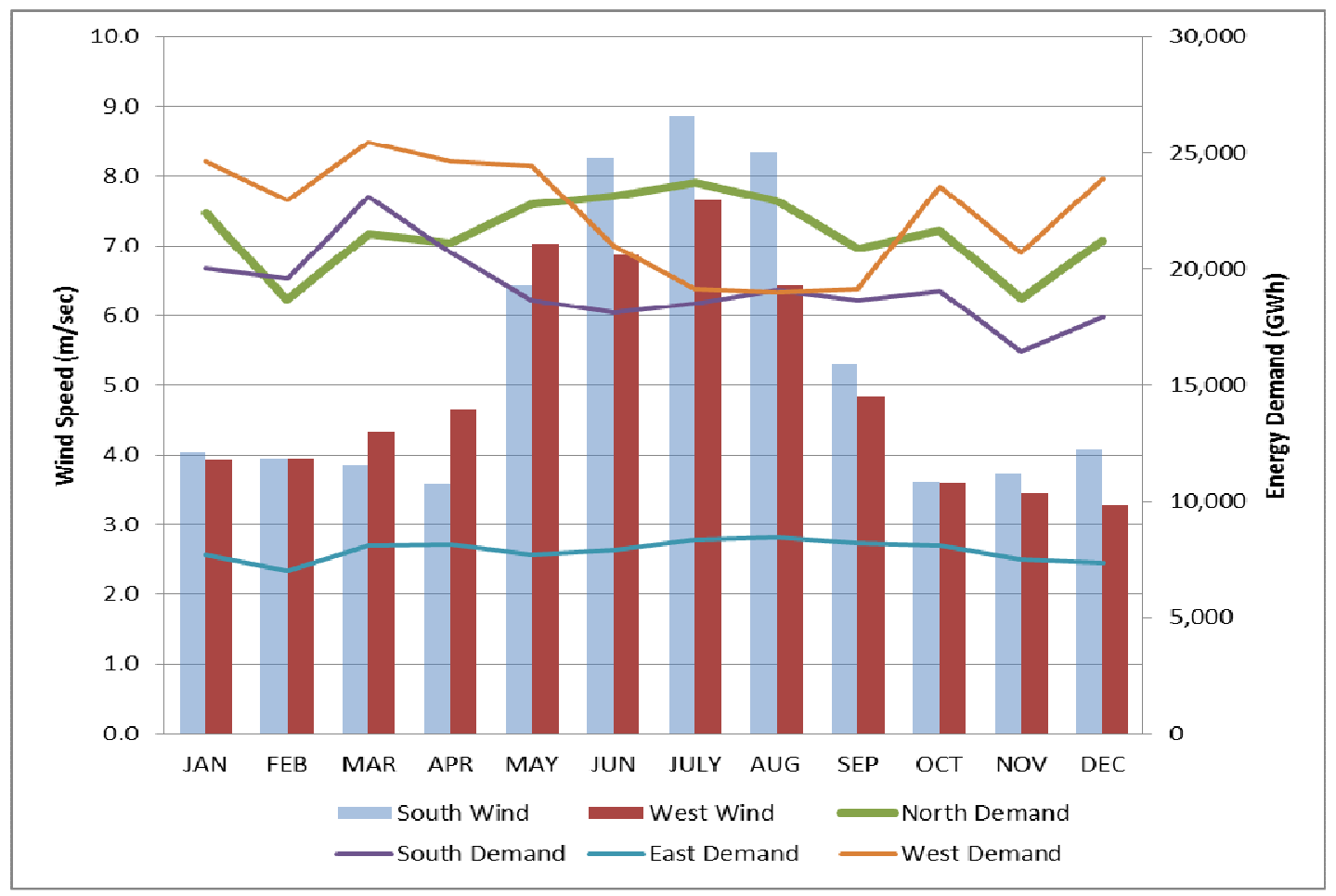

Figure 9: Seasonal Correlation of Wind Generation with Load Sources

The energy demand in Figure 9 is from CEA (2011). Wind speed is the average at 12 monitoring stations (data measured at 25m height) in the South (the states Andhra Pradesh, Karnataka, and Tamil Nadu) and 6 stations in the West (in Maharashtra and Gujarat). Hourly wind speed data was collected over a two-year time period in most of these stations. ${ }^{29}$

Note: Although wind speeds at upper heights are going to be higher than those measured at 25 meters, seasonal patterns observed at 25 meters provide a good approximation of the seasonal variation observed at higher hub heights because seasonal patterns are driven by the larger weather patterns such as the monsoon. This is confirmed by the fact that the seasonal patterns observed in actual wind generation at hub heights $>25$ meters in Maharashtra and Tamil Nadu show similar seasonal patterns to the 25 meter measurements.

For all five states, average monthly wind speeds peak during May through September. States in the South (especially Andhra Pradesh and Tamil Nadu) show somewhat higher wind speeds during some of the winter months (November and December,) than states in the West - probably as a result of the so-called "returning" monsoon. Preliminary analysis of actual hourly wind generation data in two states - Maharashtra and Tamil Nadu - confirms these observations.

\footnotetext{
${ }^{28}$ See CEA, 2011, Annex IV for the states included in different regions.

${ }^{29}$ Source: CWET (2006).
} 
In northern India, demand peaks during summer months from April through September. Hence, wind generation in the South and in the West has good seasonal correlation to the demand in the North and can potentially play a significant role in meeting the increased demand during May through September. George M. et al. (2010) find that wind in Tamil Nadu can similarly serve as an intermediate load plant in meeting electricity demand in that state, indicating that wind generation has reasonably good correlation with seasonal electricity demand.

It is likely that the use of air conditioning will continue to grow rapidly in the residential and commercial sectors, adding significantly to cooling demand all over India in all months, especially during the relatively high temperature seasons of summer and monsoon. Consequently, the gradual increase of wind speeds through summer leading to a peak in monsoon is likely to coincide significantly with growing cooling demand in India.

\subsection{Coincidence of Wind Generation with Diurnal Load Shapes at a National level and Regional Levels}

Figure 10 shows the typical diurnal pattern of wind speeds (which are highly correlated with wind generation) in the five states with highest wind potential as grouped into two groups, South (Andhra Pradesh, Karnataka, and Tamil Nadu) and West (Gujarat and Maharashtra) and the diurnal pattern of electricity demand in the largest state (in terms of electricity demand) in the West (Maharashtra).

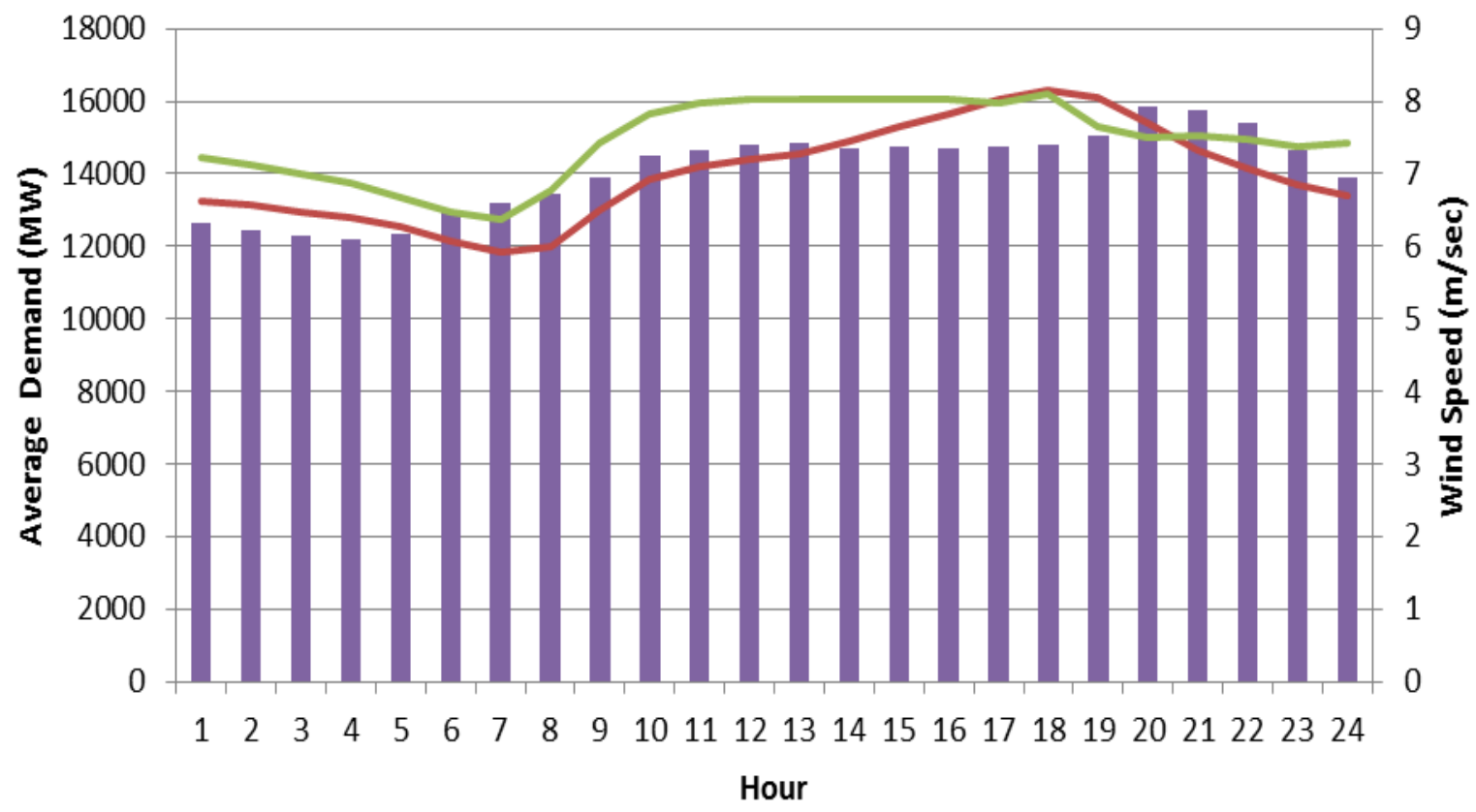

Maharashtra (Western State) Demand _ —West Wind _ _ South Wind

Figure 10: Diurnal Pattern of Wind Generation and Electricity Demand ${ }^{30}$

\footnotetext{
${ }^{30}$ Energy demand: Average hourly unrestricted demand during FY2010-11 based on hourly demand data. Source: Maharashtra State Load Dispatch Center (2011); Wind speed : CWET (2011).
} 
As seen in Figure 10, wind speeds in the South ramp up steadily from 7 am through 10 am, stay more or less constant until $6 \mathrm{pm}$, and taper off later in the day. In the West, the peak wind speeds occur during later afternoon and evening. These time periods are also typical peak demand periods in most locations, as the temperature and corresponding cooling load ramps up through the day reaching maximum demand during late afternoon and evening. In other words, the diurnal variation of wind energy availability appears to have a substantial coincidence with the diurnal variation in demand. George M. et al. (2010) show that, in the state of Tamil Nadu, wind generation can play a similar role as intermediate load plants, which indirectly indicates a good correlation of wind generation with daily high demand periods. 


\section{Conclusions and Future Directions}

The official wind energy potential estimate as described in the latest (i.e. 2010) Wind Energy Atlas of India is about $50 \mathrm{GW}$. However, two recent studies - Xi Lu (2009 and Hossain et al. (2011) - indicate that the true wind energy potential for India is at least one order of magnitude greater than the official estimate. Recent re-assessments of wind energy potential in the U.S. and China that have accounted for the improved capability of the latest wind technology (due to higher hub heights, larger rotor diameters, and better component technology) have led to substantial upward revision of the wind potential in each country. Lastly, the Wind Energy Atlas of India makes ad-hoc assumptions about the land available for wind power development instead of systematically identifying various land uses and their suitability for wind power development.

In order to address the concerns and discrepancies described above, this study - using "best practice" methods and vetted data - developed the potential wind energy available in India. Results include the following:

- The developable on-shore wind potential under the "no farmland included" scenario ranges from $748 \mathrm{GW}$ to $976 \mathrm{GW}$ (capacity factor greater than 22 percent).

- Under the "all farmland included" scenario, the potential ranges from $984 \mathrm{GW}$ to 1549 GW (capacity factor greater than 22 percent).

- The potential at high-quality wind energy sites alone (80m hub-height with a minimum capacity factor of 25 percent) ranges from $253 \mathrm{GW}$ (no farmland included) to $306 \mathrm{GW}$ (all farmland included) - more than five times larger than the current official estimate.

- Off-shore developable potential in India ranges from $214 \mathrm{GW}$ at $80 \mathrm{~m}$ hub-height (and minimum 20 percent capacity factor) to $223 \mathrm{GW}$ at a minimum 22 percent capacity factor.

More than 95 percent of the nation's wind energy potential is concentrated in just five states in southern and western India - Tamil Nadu, Andhra Pradesh, Karnataka, Maharashtra, and Gujarat. The state with the overall largest resource is Karnataka while the state with largest best quality resource is Tamil Nadu.

Under the conservative CERC norms, approximately $200 \mathrm{GW}$ of wind potential is available at a levelized cost of Rs. 5/kWh or less - at all three hub-heights and both farmland inclusion sensitivity cases. At $120 \mathrm{~m}$ hub-height (minimum capacity factor of 22 percent) and the "all farmland included" scenario, approximately $1,000 \mathrm{GW}$ of wind potential is available at Rs. $6 / \mathrm{kWh}$ or less. At least $18 \mathrm{GW}$ of wind energy potential can be developed today at less than Rs. $4 / \mathrm{kWh}$ at all three hub-heights and under both farmland inclusion scenarios.

Wind generation in the South and in the West appears to have a strong seasonal correlation to electricity demand in the North and can potentially play a significant role in meeting the increased demand during May through September. As for diurnal variations, wind generation appears to substantially coincide with the diurnal variation in electricity demand all over India, with wind speeds steadily ramping up from morning to evening.

Considering the findings of the large wind potential and these preliminary observations about reasonably good temporal correlation of wind generation with electricity demand, it is possible to imagine scenarios where wind energy can play a substantial role in India's energy mix and contribute significantly to reduction in power shortages in the short term and energy security and 
environmental sustainability in the long term. These promising results provide sufficient support for conducting further analysis (on topics such as wind integration, transmission planning, regional co-ordination, cost effective development, and land policies) and dialogue that would ensure that this large, cheap, and clean resource available in India is exploited as quickly and as cost-effectively as possible. 


\section{References}

Central Electricity Authority,CEA (2011). Load Generation Balance Report 2010-11. CEA, Government of India. Available online at: http://www.cea.nic.in/reports/yearly/lgbr_report.pdf

Central Electricity Regulatory Commission, CERC (2009). Terms and Conditions for Tariff determination from Renewable Energy Sources Regulations, 2009. Available online at http://www.cercind.gov.in/Regulations/Final_SOR_RE_Tariff_Regulations_to_upload_7_oct_09.pdf

China Meteorological Administration, CMA (2006). The Report of Wind Energy Resource Assessment in China. China Meteorological Administration, China Meteorological Press, Beijing, China.

Center for Wind Energy Technologies, CWET ( 2010). Indian Wind Energy Atlas. Center for Wind Energy Technologies. Chennai, India Available online (for purchase) at http://www.cwet.tn.nic.in/Docu/Indian_wind_atlas_brochure.pdf

Center for Wind Energy Technologies, CWET (2006). Wind Energy Resource Survey in India VII. Center for Wind Energy Technologies, Chennai, India.

Denholm, P., M. Hand, M. Jackson, and S. Ong (2009). Land-Use Requirements of Modern Wind Power Plants in the United States. National Renewable Energy Laboratory (NREL) Technical Report NREL/TP-6A2-45834.

Fingersh, L. M. Hand, and A. Laxson (2006). Wind Turbine Design Cost and Scaling Model. Technical Report. NREL/TP-500-40566. December 2006

George, M. and R. Banerjee (2009). Analysis of Impacts of Wind Integration in the Tamil Nadu Grid. Energy Policy 37(2009)3693-3700

Hossain J, et al. (2011). A GIS based Assessment of Potential for Wind Farms in India, Renewable Energy (2011), doi:10.1016/j.renene.2011.04.017

Justus, C.G., et al. (1977). "Methods for Estimating Wind Speed Frequency Distributions", Journal of Applied Meteorology, 1977, Vol. 17, pp. 351

Lu, X., M.B. McElroy, and J. Kiviluoma (2009). Global potential for wind-generated electricity. Proceedings of the National Academy of Sciences, 106, pp. 10933-10939.

Maharashtra State Load Dispatch Center (2011). Daily Report. Available online at http://mahasldc.in/reports/dailyreports/

McKinsey (2008). Environmental and Energy Sustainability: An Approach for India. McKinsey and Company.

Milligan, M., et al. (2009). Large-Scale Wind Integration Studies in the United States: Preliminary Results. In: 8th International Workshop on Large Scale Integration of Wind Power and on Transmission Networks for Offshore Wind Farms, Bremen, Germany, 14-15 October

Phadke, A (2009). "How many Enrons? Mark-ups in the stated capital cost of independent power producers' (IPPs') power projects in developing countries" Energy, Volume 34, Issue 11, November 2009, Pages 1917-1924

Planning Commission, Government of India, GOI (2011). Low Carbon Strategies for Inclusive Growth. Interim Report of the Expert Group on Low Carbon Strategies for Inclusive Growth.

Sargsyan, G. et al. (2010). Unleashing the Potential of Renewable Energy in India. Energy Sector Management Program (ESMAP).

Sathaye, J., A. Gupta (2010). Eliminating Electricity Deficit through Energy Efficiency in India. LBNL-3381E

Wiser, R., and M. Bolinger (2010). 2009 Wind Technologies Market Report. US Department of Energy, Washington, DC, USA, $88 \mathrm{pp}$.

Wiser, R., Z. Yang, M. Hand, O. Hohmeyer, D. Infield, P. H. Jensen, V. Nikolaev, M. O'Malley, G. Sinden, A. Zervos, (2011): Wind Energy. In IPCC Special Report on Renewable Energy Sources and Climate Change Mitigation [O. Edenhofer, R. Pichs-Madruga, Y. Sokona, K. Seyboth, P. Matschoss, S. Kadner, T. Zwickel, P. Eickemeier, G. Hansen, S. Schlömer, C. von Stechow (eds)], Cambridge University Press, Cambridge, United Kingdom and New York, NY, USA. http://srren.ipcc-wg3.de/report/IPCC_SRREN_Ch07

Wiser, R.H. (2010), “Understanding Trends in Overall U.S. Wind Project Performance," WindPower 2010, pp. 10-11. 


\section{Key Report Contacts}

Amol Phadke

Berkeley Laboratory

AAPhadke@lbl.gov

Ranjit Bharvirkar

Itron Inc.

Ranjit.Bharvirkar@itron.com

Jagmeet Khangura

Black and Veatch

KhanguraJK@bv.com

\section{Download the Report}

http://ies.Ibl.gov/India Wind Potential

\section{Disclaimer}

This document was prepared as an account of work sponsored by the United States

Government. While this document is believed to contain correct information, neither the United States Government nor any agency thereof, nor The Regents of the University of California, nor any of their employees, makes any warranty, express or implied, or assumes any legal responsibility for the accuracy, completeness, or usefulness of any information, apparatus, product, or process disclosed, or represents that its use would not infringe privately owned rights. Reference herein to any specific commercial product, process, or service by its trade name, trademark, manufacturer, or otherwise, does not necessarily constitute or imply its endorsement, recommendation, or favoring by the United States Government or any agency thereof, or The Regents of the University of California. The views and opinions of authors expressed herein do not necessarily state or reflect those of the United States Government or any agency thereof, or The Regents of the University of California.

\section{Ernest Orlando Lawrence Berkeley National Laboratory is an equal opportunity employer.}

\section{Acknowledgements}

We thank Dr. Pramod Deo, Chairman, Central Electricity Regulatory Commission for indicating to us the need to reassess wind potential estimates in India and for his feedback on our assessments. We thank Mr. Shashi Shekhar, Joint Secretary, MNRE, Mr. Nigam, Director, MNRE, and Mr. Upadhyaya, Director, MNRE for useful feedback. We thank Ashwin Gambhir and Ranjit Deshmukh of Prayas and E.

Sreevalsan of CWET for a review and feedback on this study. We thank Deepak Gupta of Shakti foundation for useful feedback and support in obtaining some of the data used in this report. We thank Cathie Murray and Bob Lieberman of the Regulatory Assistance Project for indicating the need for reassessment and other useful feedback. Finally, we thank Richard O'Connell and Adam Hanna of Black and Veatch, and Jayant Sathaye, Ryan Wiser, Alissa Johnson, and Nikit Abhyankar, and Andrew Mills of Lawrence Berkeley National Laboratory for their technical inputs. Any errors or omissions are those of the authors only. We thank Regulatory Assistance Project and Climate Works Foundation for the financial support for this work.

This work was supported by the Regulatory Assistance Project through the U.S.

Department of Energy under Contract No. DE-AC02-05CH11231. 